\title{
Cutting-edge capillary electrophoresis characterization of monoclonal antibodies and related products
}

\author{
Rabah Gahoual1,2, Alain Beck³, Emmanuelle Leize-Wagner ${ }^{1}$, Yannis-Nicolas François ${ }^{1}$ \\ ${ }^{1}$ Laboratoire de Spectrométrie de Masse des Interactions et des Systèmes (LSMIS), UDS-CNRS UMR 7140; Université de Strasbourg; \\ Strasbourg, France. \\ ${ }^{2}$ Division of BioAnalytical Chemistry, AIMMS Research Group BioMolecular Analysis, VU University Amsterdam, Amsterdam, The Nether- \\ lands \\ ${ }^{3}$ Centre d'immunologie Pierre Fabre; Saint-Julien-en-Genevois, France.
}

ABSTRACT: Out of all categories, monoclonal antibodies (mAbs), biosimilar, antibody-drug conjugates (ADCs) and Fc-fusion proteins attract the most interest due to their strong therapeutic potency and specificity. Because of their intrinsic complexity due to a large number of micro-heterogeneities, there is a crucial need of analytical methods to provide comprehensive in-depth characterization of these molecules. CE presents some obvious benefits as high resolution separation and miniaturized format to be widely applied to the analysis of biopharmaceuticals. CE is an effective method for the separation of proteins at different levels. capillary gel electrophoresis (CGE), capillary isoelectric focusing (CIEF) and capillary zone electrophoresis (CZE) have been particularly relevant for the characterization of size and charge variants of intact and reduced mAbs, while CE-MS appears to be a promising analytical tool to assess the primary structure of mAbs and related products. This review will be dedicated to detail the current and state-of-the-art CE-based methods for the characterization of mAbs and related products. 


\section{INTRODUCTION}

Monoclonal antibodies (mAbs) are highly complex tetrameric glycoproteins that must be extensively analytically and structurally characterized to become drug candidates $[1,2]$. This is also true for biosimilar $[3,4]$ and biobetter antibodies [5], for glyco-engineered antibodies [6] and for IgG-related products such as Fc-fusion proteins and peptides [7, 8], antibody-drug conjugates [9], bi- and multi-specific antibodies [10] and antibody mixtures [11, 12].

A plethora of separation techniques based both on liquid chromatography and electrophoresis are used for antibody characterization and homogeneity assessment [13]. These orthogonal analytical methods aim to separate the antibody main isoform from microvariants and process related impurities such as host cell proteins (HCPs) [14]. A correct primary structure assessment and extensive glyco-profiling are the cornerstone of antibody characterization. A combination of intact, middle-down, middle-up and bottom-up mass spectrometry (MS) techniques is the workflow of choice to characterize the amino acid sequence and the major post-translational modifications (PTMs) of antibodies [15]. IgG glycans represent an average of only 2-3\% of the total antibody mass, but they are one of the critical quality attributes for therapeutic candidates [16]. Micro-variants are commonly observed when mAbs are analyzed by charge-based separation techniques such as isoelectric focusing gel electrophoresis (IEF), capillary IEF (CIEF), imaged cIEF (icIEF), and ion exchange chromatography (CEX/ AEX). Many of the modifications leading to the formation of acidic and basic species have been identified by analyzing fractions collected from chromatography-based methods, with the aim of further analyzing their impact on safety, pharmacokinetics and pharmacodynamics (PK/PD). Those located in antibody complementarity-determining regions (CDRs) are often considered to be the most critical because they are surface exposed and often involved in the antigen binding [17].

In the past decade, several hundreds of papers have been published on mAbs analytical and structural characterization, and the trend will certainly continue to expend in the future. Multiple and complementary liquid chromatography, electrophoresis, spectroscopic methods and MS methods are used at all stage of mAbs discovery, preclinical and clinical development. Because of its high resolving power, simple instrumentation, miniaturized format and superior separation efficiency, capillary electrophoresis (CE) represents a powerful techniques to characterized biomolecules [18]. The different electrophoretic modes that can be employed such as capillary gel electrophoresis (CGE) [19], cIEF, iclEF [20] and capillary zone electrophoresis (CZE)[18], exhibits attractive opportunities for the characterization of mAbs and related products at different levels such as intact or reduced charge- or size-variants, isoforms, glyco-profiling and PTMs and also impurity studies. As the main handicap of CE is known to be the poor UV-detection limit, CE is fully suitable for coupling to different very sensitive detection methods such as laser induced by fluorescence (LIF) [19] and MS [21, 22]. Some reviews assessed that CE-based methods as efficient techniques for the characterization and quality control of biomolecules are fully implemented in biopharmaceutical industry $[13,23-29]$. Here we review the current and state-of-the art electrophoretic methods 
relevant in biopharmaceutical field of applications from the year 2010 to 2015 . We focused on the characterization of $\mathrm{mAbs}$ and the related product as biosimilars, ADCs and Fc-fusion proteins which represents today the fast growing class of biotherapeutic products.

\section{Capillary Gel Electrophoresis (CGE)}

\subsection{Technical considerations}

Since the 90s, CGE has known a significant concern for the characterization of proteins. Currently, this method is recognized as an essential analytical technique especially in the biopharmaceutical industry for the characterization of mAbs. CGE is a method based on the same mechanism as sodium dodecyl sulfate-polyacrylamide gel electrophoresis (SDS-PAGE). After complete reaction between SDS and proteins, SDS-protein complexes with the same negative charge are formed allowing electrophoretic separation in a sieving medium only based on their hydrodynamic radius. SDS-PAGE has been used for size-based protein separation routinely. However, this methods is also known as labor-intensive, time consuming and lacking reproducibility. The adaptation of SDS-PAGE to a capillary format permits to reduce drawbacks and brings some advantages as ease of handling, automated procedure, short analysis time and improved resolution. The transfer of SDS-PAGE to CGE is based on the replacement of the traditional slab gel by soluble polymers used as replaceable molecular sieve. This allows the separation based on hydrodynamic radius differences directly into the capillary. Proof that this method is now routinely established in industries, several companies commercialized sieving kits to perform CGE. In this electrophoretic mode and to assure that the separation is strictly based on the size differences, electroosmotic flow (EOF) has to be suppressed. The vast majority of reported CGE analysis (Table 1) were performed using bare fused silica capillary (BFS). This can be explained by the use of commercial sieving kits which contain some additives to suppress EOF. For example, the Beckman Coulter SDS-Mw gel buffer includes a high concentration of Tris-borate to eliminate EOF. However, other strategies have been described to suppress EOF and to reduce possible adsorption of protein on the inner capillary wall. The article published by Szabo et al reported the use of a linear polyacrylamide (LPA) neutral coating to enhance separation efficiency for rapid and high resolution glycan analysis of mAbs [30] . Other neutral capillary coated are described as hydroxypropyl cellulose (HPC) [31], Polyvinyl alcohol (PVA) [32, 33] and some commercial solution [34-43].

CGE is classically coupled with UV or fluorescence detection. Using a UV detection, applied wavelengths are generally $220 \mathrm{~nm}$ and more rarely $200 \mathrm{~nm}, 214 \mathrm{~nm}$ and $280 \mathrm{~nm}$. Concerning fluorescence detection, laser-induced fluorescence (LIF) has been employed to improved sensitivity. The most common condition for CGE-LIF analysis consist to the use of a laser operating at $488 \mathrm{~nm}$ for fluorescence excitation with the resulting emission signal monitored at 520 or $560 \mathrm{~nm}$. CGE-LIF of 8-Aminopyrene-1,3,6-trisulfonic-acid (APTS) labeled N-Glycan appears to 
be a methods of choice for the determination of mAbs $\mathrm{N}$-glycan profiles [35, 36]. Indeed, APTS reaction with proteins allows the derivation of a fluorophoric group and the addition of three negative charges in the glycan moety. With these modifications, electrophoretic separation can be obtained faster, with a greater efficiency and a higher sensitivity. Other strategies have been described to label $\mathrm{N}$-glycan. Michels et al developed a fluorescent derivatization method using 3-(2-furoyl)-quinoline-2-carboxaldehyde (FQ) as fluorogenic reagent for mAb analysis [44]. The same group described a quantitative impurity analysis of mAb size heterogeneity also using FQ labeling [45]. More recently, Reusch et al performed a comparative study of APTS and 8-aminonaphthalene-1, 3, 6-trisulfonate (ANTS) labeled glycan. All of the methods showed excellent precision and accuracy. Some differences were observed, particularly with regard to the detection and quantitation of minor glycan species [35].

\subsection{Applications}

For the characterization of mAbs and their related products, CGE is commonly used for protein size heterogeneity, purity, assessment of product fragment impurities characterization and aggregation and N-glycan profiling. Table 1 summarized applications of CGE in mAbs and related products in 2010-2015. Size heterogeneity represents one of the most important application of CGE for mAbs characterization. In 2012, Shi et al proposed a comparison between SDS-PAGE and CGE in mAb purity analysis. This work based on the size heterogeneity analysis reported several advantages of CGE especially in terms of accuracy and resolution of size determination as well quantitative performance [46]. Visser et al performed a comparability study between innovator approved product and biosimilar candidate of rituximab [47]. Using different methods including the size heterogeneity of intact mAb with CGE, they concluded that biosimilar candidate and originator rituximab are pharmacologically comparable with regard to anti-tumor activity, pharmacokinetic exposure and B-cell depletion. The same year, Glover et al described a size heterogeneity study of intact and reduced mAbs to assess the compatibility and the stability between pertuzumab and trastuzumab in intravenous infusion bags for coadministration [48]. Using different method as CGE-LIF, CZE and iclEF, they obtained results demonstrating no observable differences for the analysis of pertuzumab/trastuzumab mixtures store up to $24 \mathrm{~h}$ at either $5^{\circ} \mathrm{C}$ of $30^{\circ} \mathrm{C}$ (Figure 1). As Glover et al, numerous of publications described size heterogeneity of reduced mAbs (Table 1). Indeed, changes in molecular composition result in alterations of functional performance, therefore quality control and validation of therapeutic or diagnostic protein is essential. Applying reduction step in the sample preparation using a reducing reagent like tris(2carboxyethyl)phosphine (TCEP) or dithiothreitol (DTT) which allow to reduce disulfide bonds of mAbs; light chain, heavy chain and post-translational modification (PTM) can be determined. Cherkaoui et al described a CGE method to evaluate the chemical integrity of mAbs during the coupling to microparticles surface by tracking reduction fragments [49]. They followed with a great accuracy the reduction of mAbs in all intermediate isoforms 
down to single heavy and light chains. In 2013, Yin et al used CGE-LIF with reducing conditions for the characterization of mAbs between in vitro and in vivo time-course studies [50]. They demonstrated that in vivo mAbs modification cations are not fully represented by in vitro phosphate buffer or plasma incubation. To further improve the performance of CGE, Szekely et al proposed a generally applicable multi-capillary SDS-gel electrophoresis process for the analysis of mAbs for high throughput quality control. They adapted CGE method for quality analysis under reducing conditions [51]. Finally, Yagi et al proposed a quality control of mAbs using microchip electrophoresis sodium dodecyl sulfate (ME-SDS) [52]. The intrinsic properties of the microchip (separation channel measuring $14 \mathrm{~mm}$ in length and $31 \mu \mathrm{m}$ in width, high efficiency) make the ME-SDS a powerful methods in terms of minimized analysis time (<40s). Comparison study between ME-SDS and CGE on the analysis of degradation species from heat stressed mAbs showed similar results in terms of purity relative quantitation values and then introduces ME-SDS as an alternative method to the commonly used CGE methods.

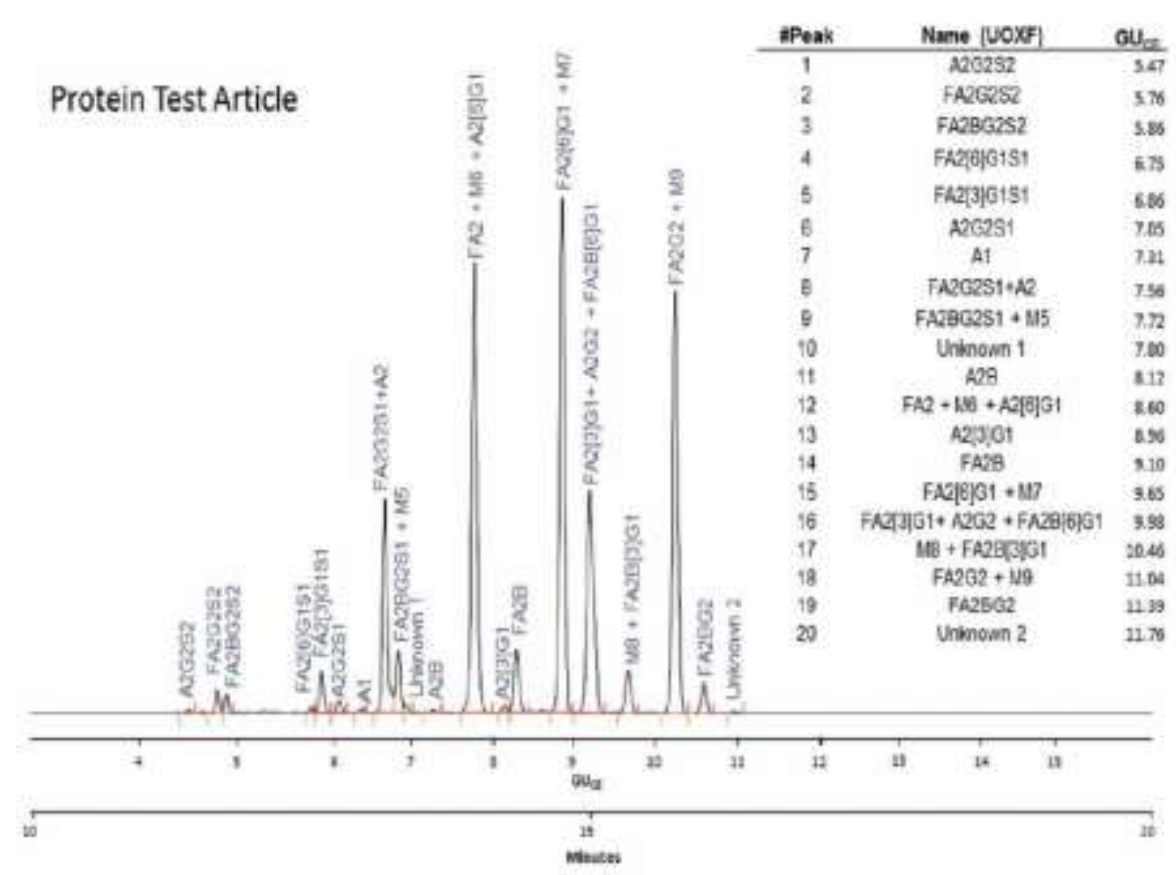

Figure 1. CE-LIF analysis trace of the APTS-labeled N-glycan profile of the Protein Test Article. The 20 most abundant peaks were integrated in all the submitted profiles and their migration times and relative and total areas were then used to determine internal precision and reproducibility of the $\mathrm{N}$-glycan mapping assay. The right panel shows the corresponding $\mathrm{GU}_{\mathrm{CE}}$ values for all integrated peaks in their migration order, as well as the name of all identified structures using Oxford notation. Reprinted from [34]. Copyright (2015), Taylor and Francis Group. 
$\mathrm{N}$-glycan profiling represent another important field of applications using CGE for mAbs characterization. As described in the technical consideration section, CGE-LIF of APTS labeled N-Glycans represents a reference methods for the determination of mAbs $\mathrm{N}$-glycan profiles. Wacker et al described the analysis of mAbs glycosylation profiles using CGE-LIF. They performed lot-to-lot variability study on major oligosaccharide profiles as quality control and noted variability of core-fucosylated forms [43]. In 2013, Hamm et al developed a CGE-LIF method to identify all the major and most of the minor glycans in a mAbs produced in a NSO cells using an important numbers of glycan standards [33]. To further enhance the performances of $\mathrm{N}$-glycan analysis using CGE in terms of analysis time, Reusch et al proposed a method using a DNA analyzer to perform high-throughput glycosylation analysis [53]. They showed that CGE-LIF analysis with DNA analyzer can generate data that help to keep a production process within the desired design space and assess that a comparable drug substance is being produced after process changes. More recently, Szekrényes et al performed an inter-laboratory study composed by biopharmaceutical companies, universities, analytical contract laboratories and national authorities in the United States, Europe and Asia, to evaluate the reproducibility of sample preparation and analysis of N-glycan using CGE-LIF. Results demonstrated low variability and high reproducibility, both within any given site as well across all sites. This work indicates that CGE-LIF method can be established as a standard N-glycan analysis platform appropriate for general use (clone selection, process development, lot release, etc.) within the industry [34]. Even if mAbs represent the major class of biotherapeutics analyzed by CGE, some articles on ADCs and FC-fusion proteins begin to be published. Indeed, Le et al described the profiling of a based ADCs using different analytical methods (hydrophobic interaction chromatography (HIC), CGE, HPLC). They developed a mathematical approach using inputs from CGE and HIC to determine the positional isomer distribution within a population of ADCs [54]. Concerning Fc-Fusion protein, Hapuarachchi et al developed with success a non-reducing CGE method to monitor disulfide scrambled forms during purification process [55] and Wang et al studied the characterization of Fc-fusion protein aggregation [37]. Implementation of CGE in biopharmaceutical industries is illustrated by the numbers of these articles published by scientists coming from R\&D departments of companies. CGE method are applied to control the consistency, purity and stability of mAbs in the quality control laboratories of Genentech, Merk, Pfizer, Amgen, Roche, Sandoz and Bracco for example.

\section{Capillary Isoelectric focusing (cIEF) and imaged cIEF (icIEF)}

\subsection{Technical considerations}

Similar to the development of CGE according to SDS-PAGE, CIEF is a method based on the mechanism of IEF slab gel. The separation of the proteins is based on their isoelectric points ( $p / s)$ in a capillary [56]. The classical workflow consists of the use of a basic catholyte, generally sodium hydroxide, placed at the cathode and an acidic anolyte, generally phosphoric acid, placed at the anode. A mixture of ampholytes and sample filled up the whole capillary. 
Applying an electrical field and due to ampholytes properties, a pH gradient is established in the capillary. As a first step, protein focused along the $\mathrm{pH}$ gradient until the region with an equal value between the local $\mathrm{pH}$ and it own $\mathrm{pl}$. In this region, the electrophoretic mobility of the sample is zero due to the absence of apparent charge bearing by the protein. As a second step, electrophoretic or hydrodynamic mobilization is implemented to force the sample to move toward the UV detection. However, the mobilization step could have negative effects on the migration time and on the resolution due to possible peak broadening. Because of these drawbacks, whole-column imaging CIEF (iclEF) has been established to achieve faster separation with greater resolution, better reproducibility and reduced sample volume. Indeed, the short capillary length $(5 \mathrm{~cm})$ leading to reduce analysis time and then allows to perform high-throughput experiments. In addition, using iclEF enabled real-time monitoring of the focusing process. Then no mobilization step is useful in icIEF workflow. Presently, iclEF is becoming a reference method for the characterization of biotherapeutics.

To ensure good focusing process in CIEF and icIEF, no hydrodynamic pressure should be applied and EOF has to be suppressed. To eliminate EOF, neutral capillaries consisting to neutralize inner surface of capillary with dynamic or permanent coating were used (Table 1). Concerning iclEF, the most popular commercial instrument iCE280 proposed a neutral fluorocarbon capillary which is used in every reports.

Large cut-off is observed because of the strong absorbance of ampholytes at lower wavelengths, almost all current CIEF and icIEF use UV detection at $280 \mathrm{~nm}$. For cIEF, on-line UV detector are available in all commercial CE apparatus. Regarding iclEF, real-time monitoring is performed using a CCD camera. To further improve the performance of cIEF in terms of sensitivity, Michels et al described a multiplexed iclEF immunoassay with chemiluminescence detection for the characterization of mAbs [57]. With different steps of immobilization and conjugation, they were capable of detecting product impurities even in the presence of excess host cell protein lysate eliminating any sample clean up before analysis. Mass spectrometry detection (MS) also appears to be a good candidate to enhance the sensitivity. The hyphenation between CIEF and MS allowed to perform separation based on p/s and $\mathrm{m} / \mathrm{z}$ ratio and then to obtain additional structural information. However, due to the presence of salts and ampholytes, technical issues curbed the development of this coupling. In 2012, Zhu et al realized a rapid and reproducible cIEF-MS method for host cell protein analysis of mAbs [58]. After optimization of the anolyte, catholyte and sheath liquid, they performed the identification of $3.5 \mathrm{pmol}$ of BSA digest which highlights the potential of this coupling.

\subsection{Applications.}


CIEF and icIEF has become reference methods for the characterization of charge heterogeneity for biopharmaceutical companies. Intact and reduced therapeutics likewise PTMs can be identified using this electrophoretic mode. Table 1 summarized applications of cIEF and icIEF in mAbs and related products in 2010-2015.

In 2011, Lin et al reported a sensitive cIEF method for determining the charge heterogeneity of mAbs [59]. Under optimized conditions they observed the separation of both acidic and basic species of the mAbs. While concentration range of $0.03-0.20 \mathrm{mg} / \mathrm{mL}$ were obtained, the method also was used for C-terminal lysine variants characterization and glycosylation profile analysis. More recently, Bonn et al proposed a clEF method for the development of robust protein reagent characterization in the clinical immunodiagnostic [60]. They optimized methods to achieve as much as 20 -fold increase in the number of consecutive runs before capillary degradation. clEF method was developed for confident identification of differences in charge-related characteristics of proteins. The same year, Cao et al described a cIEF analysis of trastuzumab biosimilar in terms of charge profiling and stability testing [61]. They realized optimization on focusing time and separation temperature to get a robust method to analyze charge variants. They reported that this method can be applied to evaluate stability, determination of lot consistency and purity assessment, and concluded that CIEF was a promising tool for the routine analysis of therapeutic mAbs. This conclusion can be illustrated by the work of Suba et al which considered that cIEF is a basic and highly accurate routine analytical tool to prove identity of protein drugs in quality control and release tests in biopharmaceutical industries especially with the use of commercial standardized kits [62]. However, they also proved that it is still possible to developed and validated cIEF methods for identification testing of mAbs drug product. Their method was validated according to the recent ICH guidelines (Q2(R1)). Another recent work performed by Raymond et al about the production of $\alpha 2,6$-sialytated IgG1 in CHO cells proved the usefulness of cIEF as part of other analytical methods in the characterization of therapeutic proteins [63]. Authors performed clEF to estimate the nature of the sialic acid linkage by sequential sialidase digestions. To assess cIEF as a reference method in biopharmaceutical industries, Salas-Solano et al organized an inter-laboratory comparison [64]. International team of 12 laboratories from 10 independent biopharmaceutical companies in the United States and Switzerland were formed to evaluate the precision and robustness of CIEF to determine the charge heterogeneity of $\mathrm{mAbs}$. The different laboratories determined the apparent $\mathrm{p} /$ and the relative distribution of the charge isoforms of mAbs. They concluded in a validation of the appropriate use of cIEF in the biopharmaceutical industry in support of regulatory submissions.

An analogous inter-laboratory study was performed by the same group on the robustness of iclEF technique for the analysis of mAb [65]. Results showed an important similarity with the precedent inter-laboratory study [64]. They concluded that icIEF is a robust technology (i) to determine the charge heterogeneity of mAb, (ii) to be used as an alternative or complementary methodology to conventional cIEF technology and (iii) to be a reference 
method both in process development and quality control of biopharmaceuticals. Numbers of papers illustrated the use of this technique in the process development $[39,66]$. To further improve the performance of mAbs characterization using CIEF, Meert et al performed mAb charge heterogeneity study by preparative immobilized pH gradients (IPG) [67]. They realized IPG-IEF fractionation followed by cIEF analysis. Results extended characterization to elucidate the composition of the acidic, main, and basic species observed in the cIEF profile. Dada et al reported a similar study using icIEF in place of clEF [68].

To evaluate the charge heterogeneity of mAbs with shorten analysis time and in an easier manner, Kinoshita et al developed a microchip icIEF (mclEF) [69]. Authors compared their method with reference clEF technique. Results showed a decrease by 10 -fold analysis time and an excellent correlation of calculated p/ values and percent relative amounts of each charge variants. However, they confessed the lack of automation and the need of improvements in functionalization for a commercial use in the biopharmaceutical companies.

Similar to CGE analysis, mAbs represents the major class of biotherapeutics analyzed by cIEF and iclEF. However in 2012, Anderson et al demonstrated the applicability of an iclEF method for the charge heterogeneity of a heavily sialylated Fc-fusion protein for biosimilar development [70]. More recently, Wu et al performed the structural characterization of a Fc-fusion protein named conbercept by different analytical methods. They measured the $\mathrm{p} /$ of deglycosylated conbercept using CIEF method [71]. Valierre-Douglass et al reported the charge heterogeneity study of heat-stressed mAbs and ADCs using icIEF [72]. They observed important variation of basic variants with increasing storage temperature (Figure 2). This article and some others prove that CIEF and iclEF can be implemented in the analysis of charge heterogeneity in ADCs $[73,74]$.

\section{Capillary Zone Electrophoresis (CZE)}

\subsection{Technical considerations}

CZE is known as the most straightforward and popular electrophoretic mode used. The separation is based on the difference of electrophoretic migration of analytes in a background electrolyte (BGE) depending on their chargeto-size ratio [75]. The classical workflow consists to fill up the capillary with BGE. After hydrodynamic or electrokinetic injection of sample, an electrical field is applied allowing the electrophoretic migration of analytes. The most common used detection mode is UV detection mainly fixed at $200 \mathrm{~nm}$ or $214 \mathrm{~nm}$ for mAbs characterization (Table 1). An important issue of CZE with a UV detection is the poor sensitivity. However, one advantage of CZE, as compared to CGE and CIEF, is on the better compatibility with MS detection. Despite some issues about the nature of BGE (high salt concentration, volatility...), MS detection enhances structural characterization of sample. A complete section about the hyphenation between CE and MS will be dedicated further in this review. 
Similar to CGE and cIEF, charge variants characterization of mAbs using CZE needs to be performed without or with a reverse EOF.
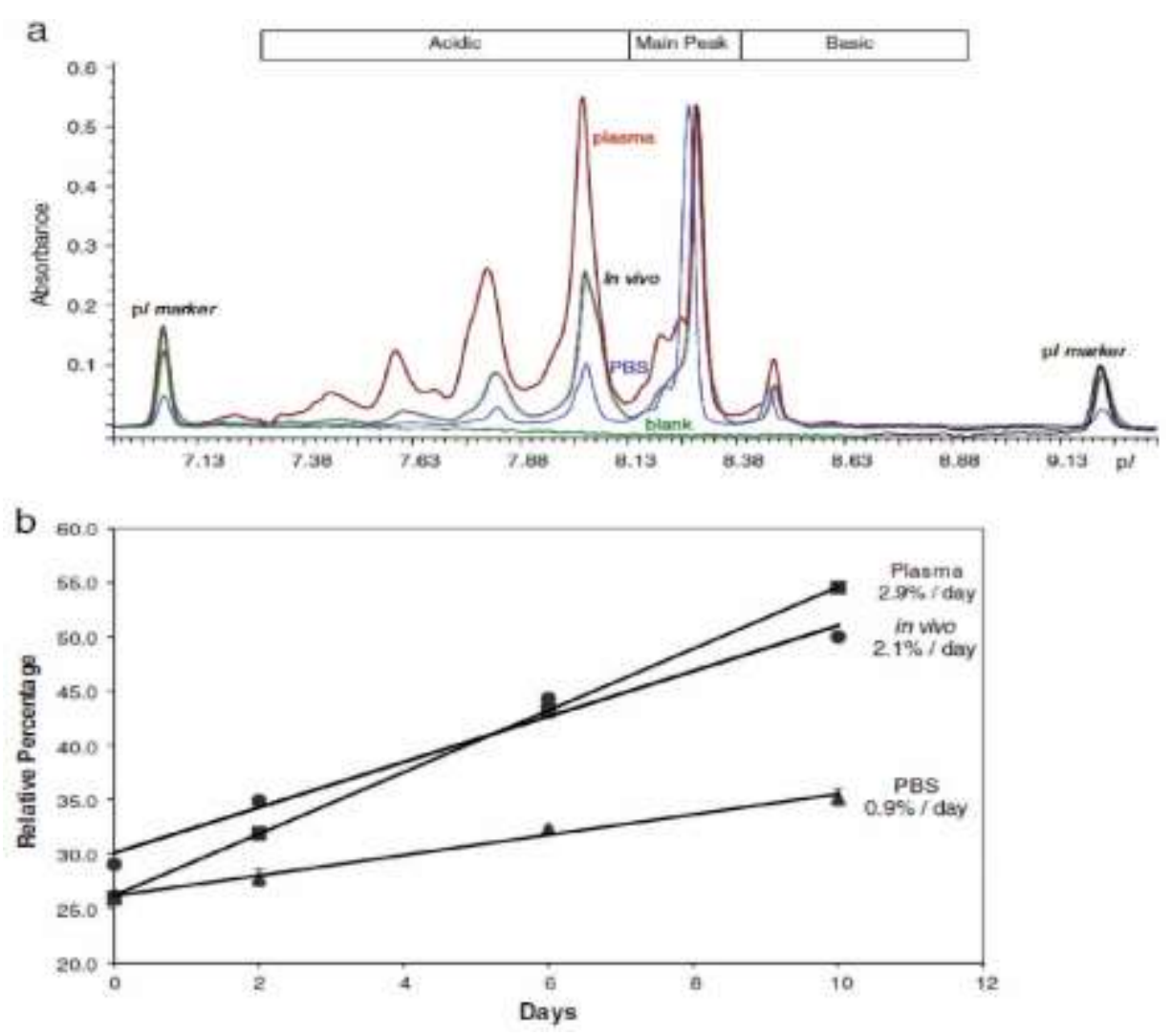

Figure 2. (a) iclEF electropherograms of mAb-1 after 10 days PBS, plasma incubation, and in vivo circulation. Electropherograms are normalized based on the main peak. The relative percentage of the acidic variants is dramatically increased during plasma incubation. Plasma control is labeled as "blank". (b) The iclEF analysis of mAb-1 shows an increase in the acidic peaks during PBS and plasma incubation, and in vivo circulation. Each time point for PBS and plasma-incubated samples are in triplicate. Error bars represents standard deviations. Acidic variants increase with rate of $0.9 \%, 2.9 \%$, and $2.1 \%$ per day during PBS $(\boldsymbol{\Delta})$, plasma $(\boldsymbol{\bullet})$ incubation, in vivo circulation $(\bullet)$, respectively. Reprinted from [50]. Copyright (2013), Springer.

Moreover, due to the negatively charged silanols surface of classical BFS, positively charged proteins will tend to interact and then adsorb to the inner capillary wall. These phenomena involve significant decrease of electrophoretic resolution caused by peak broadening. Different approaches were described to reduce protein adsorption. The most frequently applied strategy consists to shield the protein from the BFS by the modification of the inner surface of capillary with a dynamic or a permanent coating. Due to their ease of use, dynamic coatings, as hydroxypropyl-methyl cellulose (HPMC) or polybren (PB), are often set up for the characterization of charge heterogeneity of mAbs (Table 1). As buffer additives, dynamic coatings adsorb the surface of the capillary during the electrophoretic separation but need regular regeneration step. Another way is the use of permanent coatings. Indeed, 
to avoid regeneration step and possible release which can compromise the compatibility with MS detection, permanent coating, consisting to covalent linkage to the capillary wall, appears to be the best option. Many procedures are described in the literature to realize home-made coatings [76]. Note that commercial capillaries also are available. An important paper about static coating performances (commercial or not) for the analysis of mAbs by CZE has been reported by Gassner et al [77]. Major trends were observed as for example (i), for positive coating the EOF and the mAb effective mobility need to be relatively close and (ii) for neutral coating, EOF has to be near zero to obtain the best resolution. As a general conclusion, authors showed that no coatings totally eliminates protein adsorption and that separation performances are strongly dependent of BGE composition and BGE pH. As a solution to enhance the reduction of protein adsorption, some reports described the use of a modifier, as triethylenetetratmine (TETA) [78-80] or Tween 20 [77], directly added to the BGE.

Finally, to further improve the performance of CZE methods, microchip zone electrophoresis (MZE) was developed to allow the characterization of mAbs charge variants with a drastic reduction of analysis time. Different commercial devices are available coupled with UV, MS or chemiluminescence detection (Table 1).

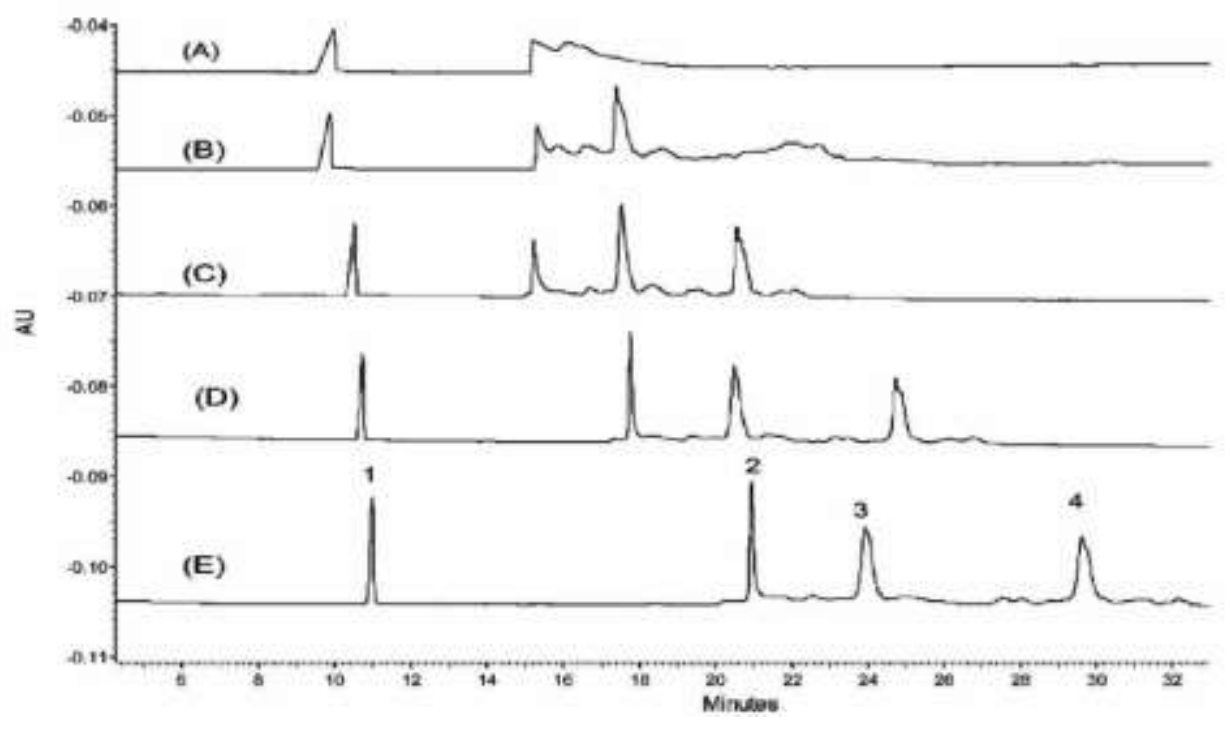

Figure 3. Effect of EACA concentration on the separation of $\operatorname{lgG} 1$ and $\operatorname{lgG} 2 \mathrm{mAbs}$ in a bare fused silica capillary. Bare capillary $(40+10) \mathrm{cm} \times 50 \mu \mathrm{m}$ i.d.; capillary temperature $25^{\circ} \mathrm{C}$; separation buffer (A) 50, (B) 100, (C) 200, (D) 400, and (E) $600 \mathrm{mM}$ EACA-acetic acid, 0.1\% HPMC, pH 5.4; voltage 24 kV; injection 0.5 psi × 5 s; detection UV 214 nm. Peak identity: peak 1, histidine; peak 2, IgG1 mAb; peaks 3 and 4, IgG2 mAbs. Reprinted from [78]. Copyright (2010) American Chemical Society.

\subsection{Applications.}

As compared to CGE and CIEF, mAbs remain relatively less investigated by CZE, probably due to the protein adsorption issues previously described. However, since 2010, a great number of reports described CZE-based 
methods for the characterization of mAbs charges variants for the quality control of biopharmaceuticals companies in terms of purity, quantitation and stability testing. Table 1 summarizes applications of CZE articles for mAbs and related products in 2010-2015. Precursor in this field of application, Ruesch's group from Pfizer reported two major articles on the separation of intact mAbs charge variants using CZE $[78,79]$. They developed experimental conditions which to date represent a reference for the analysis of mAbs using CZE with a UV detection. First of all, they optimized the $\mathrm{BGE} \mathrm{pH}$ between 4.5 and 6.0. They demonstrated that $\mathrm{pH}$ is a major parameter to increase selectivity of charge variants separation. Second of all, they used a BGE based on $\varepsilon$-aminocaproic acid (EACA). EACA is an ampholytic compound which allow to decrease adsorption as compared to classical buffer (Figure 3). And finally, in the aim to assess the robustness of the method, they added HPMC and TETA in the BGE to perform a dynamic coating and to nearly cancel any protein adsorption. Currently, significant number of reports of CZEbased methods about charge variants of mAbs implement BGE composed of EACA at pH 4.5 to 6.0. Only the concentration of EACA and the nature of coating and additives can vary [48, 77, 80-83]. To evaluate CZE as a reference method in biopharmaceutical industry, Moritz et al organized an inter-company study to assess CZE for charge heterogeneity testing of mAbs. They proposed a generic CZE method [80] to 11 participating labs. It was shown that CZE is applicable across a broad p/ range between 7.4 and 9.5. Coefficient of correlation for linearity, precision by repeatability and accuracy by recovery were 0.99 and around $1 \%$ and $100 \%$ respectively. This demonstrates that CZE is suitable as a new powerful platform technology for the charge heterogeneity testing of mAbs in quality control laboratories of biopharmaceutical companies. Glover et al illustrated this conclusion by the use of CZE as an orthogonal method in the stability study of pertuzumab and trastuzumab admixture in intravenous infusion bag [48]. CZE as well as CGE and icIEF analysis were implemented to conclude of no observable differences in the pertuzumab/trastuzumab mixtures store up to $24 \mathrm{~h}$ at either $5^{\circ} \mathrm{C}$ of $30^{\circ} \mathrm{C}$. The same year, Espinosa-de la Garza et al used CZE as an analytical platform to characterize charge heterogeneity of mAbs and biosimilar candidates (Figure 4) [83]. Despite a good robustness of the method, they showed the need of orthogonal methods to obtain structural information and then to assess biosimilarity. To further improve the performance of CZE separation in terms of analysis time, Wheeler et al [84] and Han et al [82] proposed MZE methods for high throughput profiling of charge heterogeneity in mAb. MZE-based methods achieved from 8- to 90-fold faster separation time over conventional methods while maintaining comparable resolution and profiles of charge variant distributions. In another work, Antes et al proved the suitability of MZE method for impurity testing of mAbs [85]. They compared their method to conventional SDS-PAGE and concluded on the MZE advantages in terms of faster separation and convenience of handling the microfluidics-based technology. Finally, Jacoulet et al proposed a fast and reliable CZE method combined to a cationic capillary coating to identify the most widely used mAbs for cancer therapy [86]. Very satisfactory RSDs and intraday RSDs of mAbs retention time (less than $0.60 \%$ and $1.3 \%$ respectively) were 
obtained. This work demonstrates the potential of CZE to be suitable for rapid identification of mAbs for routine application in hospital.
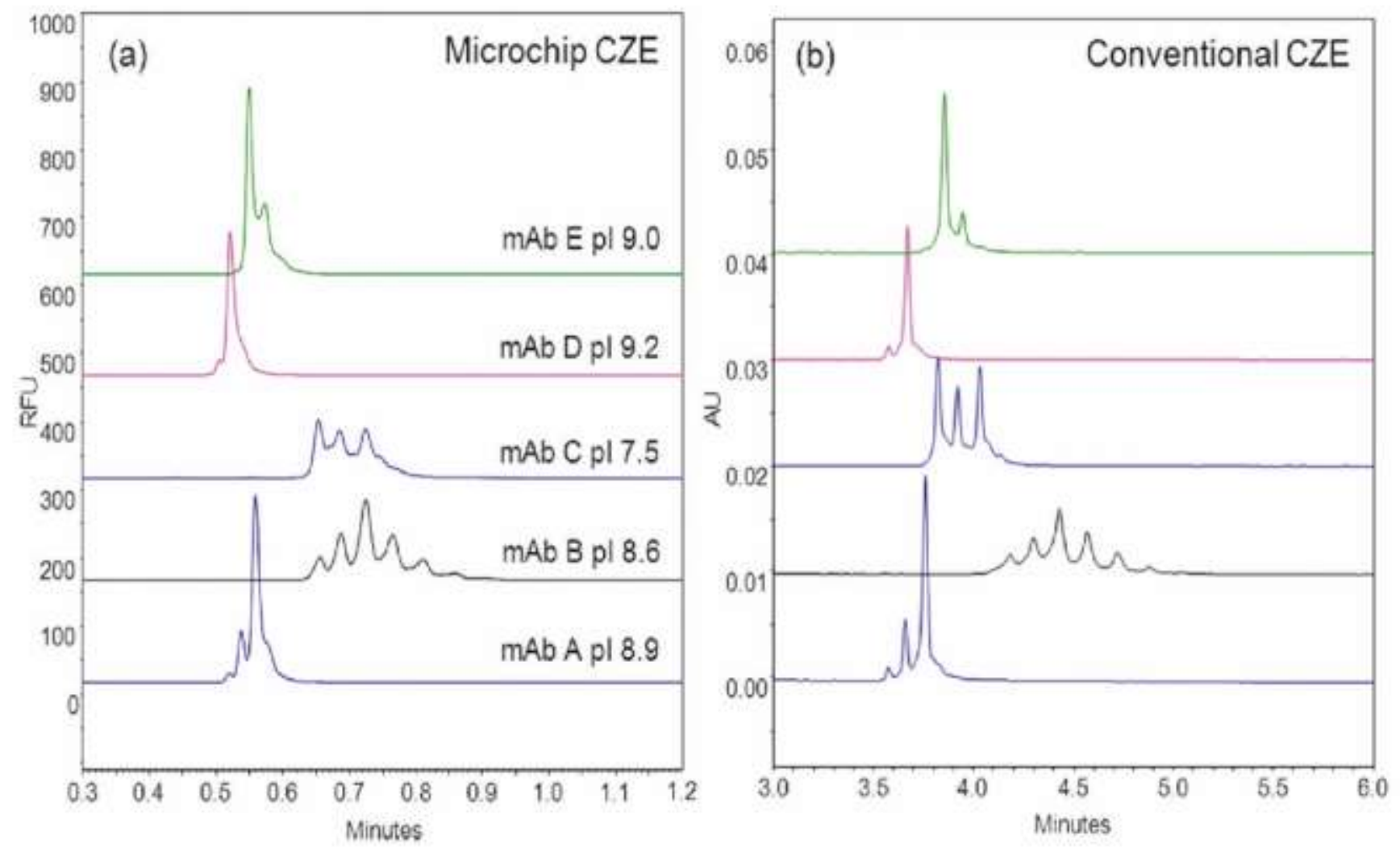

Figure 4. Comparison of microchip CZE (a) and conventional CZE (b) for five marketed antibody therapeutics. The main peak pl values determined by iclEF are indicated. For $m A b C$, the pl values of the three major peaks from left to right are 7.81, 7.63, and 7.46, respectively. Reprinted from [82]. Copyright (2011) American Chemical Society.

\section{Capillary electrophoresis - Mass spectrometry (CE-MS)}

\subsection{Technical considerations}

As the introduction of electrospray ionization (ESI-MS) and matrix assisted laser desorption ionization (MALDI-MS) mass spectrometry extended the field of application of MS to biomolecules, CE appeared rationally as a hyphenated separation technique potentially enabling the analysis of complex samples. Indeed among other type of application, CE in its different separation modes demonstrated to be particularly adapted to separate biomolecules such as ribonucleic acids, peptides or proteins. Therefore capillary electrophoresis coupled to mass spectrometry (CE-MS) was implemented shortly after the introduction of these ionization techniques [87]. For CE-MS coupling implementation, the major constraint lies in the necessity to maintain the electric field to perform the electrophoretic separation while the capillary outlet has to be positioned inside the source. To overcome this limitation, 
several interfacing designs have been developed by different research groups. Early developed CE-MS interfacing systems relied on a conductive sheath-liquid, connected to the outlet electrode of the CE system, continuously injected to maintain the continuity of the electric field. Considering the limited volume of sample that can be injected onto the capillary, the dilution effect generated by the addition of the sheath-liquid tends to lower the sensitivity therefore going against one of the major advantage of MS. However it is important to note that intensive progress have been made in the last decade regarding CE-MS interfacing. These efforts have led to the commercial introduction of several CE-MS interfaces allowing to perform highly sensitive CE-MS experiments which were previously reserved to research groups possessing CE-MS hyphenation specific expertise [88-90].

Currently CE-ESI-MS is by far the most common type of coupling implemented in CE-MS experiments. Indeed operating conditions of CE are compatible with online coupling with ESI-MS. CE-ESI-MS interfaces can be sorted in three different categories based on the principle used to maintain the electric field continuity: sheath-liquid interfaces, liquid junction interfaces and sheathless interfaces. Recently, Kleparnik published a review describing in details the different methodologies and recent developments in CE-ESI-MS interfacing [91]. Due to its intrinsic characteristics, CE appears as particularly favorable to the ESI ionization process. EOF generated during CE experiments represents a few tenths of $\mathrm{nL} / \mathrm{min}$, depending on the nature of the BGE used, which is suitable with the formation of a nanoESI guaranteeing an optimal ionization efficiency. Additionally, capillary inner diameter is commonly below $100 \mu \mathrm{m}$ which allows the production of thin droplets and favors ions production. Recent progress achieved in CE-ESI-MS interfacing enables to take the most from the characteristics of both techniques and instigate the interest for CE-ESI-MS analysis especially due to the different selectivity provided by the electrokinetically driven separation. CE-MS analysis can be envisage for the characterization of mAbs on every structure level from the quaternary structure down to the primary structure and even post-translational modifications characterization.

\subsection{Applications}

\subsubsection{Amino acid sequence characterization and peptide mapping}

Although produced using highly accurate recombinant technologies, mAbs amino acid requires to be characterized to ensure the safety of the product and prevent the occurrence of amino acid substitution due to variation during the production or storage process for example. Biacchi et al described the development of an offline CZE-MALDIMS system allowing the automatic deposition of the CZE outlet directly of the MALDI plate followed by matrix deposition. The CZE-MALDI-MS method developed was used to perform the peptide mapping of trastuzumab showing sequence coverage of $92 \%$ and $100 \%$ respectively for the heavy chain (HC) and the light chain (LC) [92]. Peptide mapping can also be performed using CZE-ESI-MS, Gennaro et al showed the analysis of Lys-C digest for 
several mAbs, in combination with LC-MS analysis, to characterize completely the amino acid sequences of the studied mAbs demonstrating the interest of using in concomitance the selectivity of both techniques because of their complementarity [93]. Whitmore et al used a sheathless CE-ESI-MS analysis to perform the peptide mapping of therapeutic mAbs through tryptic digestion. Results obtained were compared to the peptide mapping results observed using LC-MS and sheath-liquid CZE-ESI-MS. Results reported demonstrate the possibility to obtain the complete sequence coverage using sheathless CZE-ESI-MS. Data generated showed the characteristics of CZE to separate short hydrophilic peptides (down to single amino acids) which tend to be difficult to identify in LC-MS experiments because of their elution in void volume [94]. Gahoual et al developed a methodology implementing sheathless CZE-ESI-MS/MS for the characterization of several mAbs including trastuzumab and cetuximab. This method relies on an optimized sample preparation protocol enhancing digestion efficiency and improving sample compatibility with the CZE separation conditions. This method integrates tandem MS to base peptide identification on mass measurement in parallel with fragmentation spectra reinforcing the confidence of the identification and giving precious information regarding the amino acid sequence. Results described proved from a single injection corresponding to $16 \mathrm{ng}$ of digested mAbs to systematically obtained $100 \%$ sequence coverage considering strictly peptides without miscleavages [95]. Also data allowed to characterize simultaneously to the amino acid sequence, different type of post-translational modifications hotspots including glycosylation, $\mathrm{N}$-terminal glutamic acid cyclization, methionine oxidation, asparagine deamidation and aspartic isomerization. Results showed in the case of PTMs characterization, the possibility to separate the modified peptides from its intact homologous due to the separation selectivity of CZE therefore improving sensitivity and enabling confident estimation of modification levels by preventing the occurrence of ion suppression [96, 97]. Similar results were reported by Lew and coworkers attesting the transferability of this methodology [98]. This CZE-ESI-MS/MS method was applied in the context of biosimilarity assessment. CZE-ESI-MS/MS data from approved mAbs trastuzumab and cetuximab were compared to their respective biosimilar candidates. Results reported the ability in a single injection of each sample to characterize a difference of a single amino acid between trastuzumab and the corresponding biosimilar candidate. Using the same datasets, every PTMs hotspots reported for these mAbs could be successfully characterized and relative modification levels could be compared [99]. Recent research demonstrates the relevance of using CZE-ESI-MS analysis to characterize the amino acid sequence of mAbs. CZE selectivity proved to be of interest especially by allowing the separation and successful transfer to the MS of every single peptide generated from tryptic digestion regardless of their chemical structure enabling complete sequence coverage in a robust manner. Results reported using CZE-ESI-MS/MS allow to position this method not solely as a routine analysis to confirm recombinant mAbs production but also as a powerful tool which could improve R\&D pipeline by providing comprehensive data regarding the amino acid sequence and post-translational modifications. 


\subsubsection{Glycosylation characterization}

Glycosylation is one of the major critical quality attribute (CQA) of therapeutic mAbs. Glycosylation can influence different properties of mAbs including solubility, half-life and pharmacokinetic (PK) which are crucial considering their use as therapeutic treatments. Gennaro et al reported the separation and analysis of glycopeptides isolated from Lys-C digest using CZE-ESI-MS. In the same research article, they described the use of CZE-ESI-MS to analyze APTS labeled released glycan in negative ionization mode. Results showed successful characterization of the major $\mathrm{N}$-glycosylations and six O-glycosylation sites with the possibility in some cases to evaluate the site occupancy [93]. Later on the same group reported the development of a method using PVA coated capillary equipped on a CZE-LIF/ESI-MS instrument for the analysis of APTS labeled glycans released from mAbs samples. They demonstrated that the suitability of this method to characterize released glycan as 10 different glycoforms could be identified for the studied mAbs including afucosylated glycans and some containing sialic acid [100]. Bunz et al recently described the development of a CZE-ESI-MS method using a basic BGE to perform the analysis of released glycans either for charged native glycans as well as APTS labeled glycans in the same experiment. They were able to identify 15 different glycosylations obtained after released from a therapeutic antibody sample showing the relevance of the method to ease characterization of unknown glycosylation. They studied the influence of APTS labeling on ionization intensity determining that labeling decreases by 3 times signal intensity [101]. In parallel, Bunz and coworkers developed another CZE-ESI-MS employing an acidic BGE. They performed a systematic and quite complete study of the different parameters of the method to determine the parameter influencing significantly glycan separation and proposed optimized conditions [32]. Data obtained from mAbs tryptic digest by Gahoual and coworkers using sheathless CE-ESI-MS/MS were also used to characterize glycosylations. By using fragmentation spectra of tryptic glycopeptides, they could locate the position of each glycosylation sites and perform site dependent characterization integrated in the same experiment as the amino acid sequence characterization. MS/MS spectra recorded allowed to characterize the structure of the different glycosylation identified and intensities enabled estimation of relative abundance of each glycoform [96]. The same group applied this methodology in the context of biosimilarity assessment and demonstrated the possibility to distinguish faint differences in glycosylation profiles $[99,102]$.

\subsubsection{Middle-up analysis}

Middle-up characterization is performed by submitting therapeutic mAbs sample to limited digestion prior to analysis. This methodology is meeting recently a growing interest because it gives the opportunity to focus investigation on specific parts of the protein, Fab part or Fc part for example, while limiting the complexity which may arise 
from the heterogeneity of the rest of the protein. Development of middle-up analysis has been made possible by the introduction of proteolytic enzymes particularly specific for IgG such as streptococcal endopeptidase IdeS [103]. Limited digestion has also the advantage of not requiring to complete proteolytic digestion which may induce endogenous modifications of the mAbs during the analysis process [104]. Due to the absence of stationary phase and the electrophoretic mobilization of analytes during the separation, $\mathrm{CE}$ is a technique particularly suitable for the separation of fragments generated from limited digestion of mAbs. Similarly to CZE-UV, one of the major issues for middle-up and intact protein analysis is on the possible protein adsorption on the inner capillary wall due to non-protonated silanol groups remaining. As previously described different approaches were described to reduce protein adsorption (dynamic or permanent coating). Concerning MS detection, permanent coatings as HPC or LPA are preferred. Indeed, to avoid regeneration step and possible release which can compromise the compatibility with MS detection, permanent coating, consisting to covalent linkage to the capillary wall, appears to be the best option.
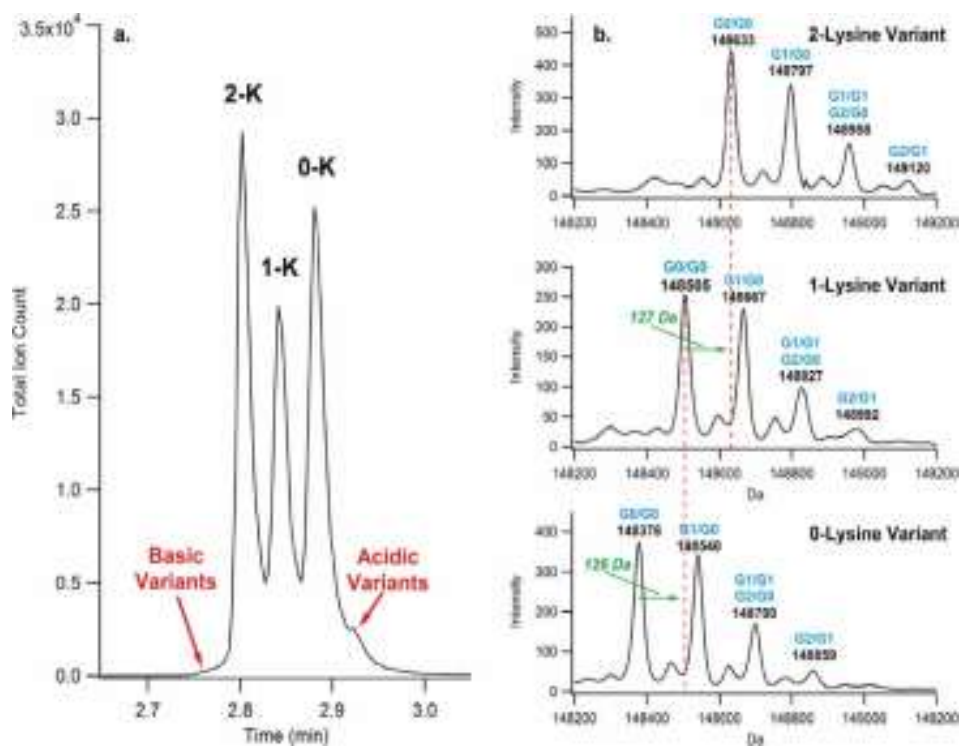

Figure 5. (a) Separation of intact Infliximab charge variants using a $23 \mathrm{~cm}$ APS-PEG450 coated device at approximately $600 \mathrm{~V} / \mathrm{cm}$. Identified lysine variant bands are labeled as 2-K, 1-K, and 0-K. (b) Deconvoluted mass spectra for each lysine variant. Glycosylation structures are labeled above the mass of each peak. Reprinted from [109]. Copyright (2013) American Chemical Society.

Based on offline CZE-MALDI/ESI-MS instrumentation implemented, Biacchi et al could demonstrated the separation of the different type of fragments generated consequently from IdeS digestion of cetuximab using HPC capillary. Therefore they were able to characterize independently the $\mathrm{N}$-glycosylation sites present respectively on the Fc and Fd part of the mAb. Identification of 8 glycoforms for Fc fragments and 6 glycoforms for Fd fragments could be achieved. Additionally, described results showed in the case of Fc fragments the complete separation on lysine 
variant species [105]. Furthermore using a similar approach, they could demonstrate the formation of dimers due to the IdeS digestion which revealed to be stable enough to be conserved when the analysis was performed in native conditions [106]. Data recently published from Zhao et al showed the development of a CZE-ESI-MS method applied to the analysis of reduced mAbs. They demonstrated using this method the possibility to separate the HC and the LC. In addition they could successfully identified a mixture composed of several reduced mAbs [107]. The CZE-ESI-MS method developed by Han and coworkers was used to perform a detailed middle-up characterization of a therapeutic IgG1 using different sample treatment. Data presented proved the separation of the HC and the LC when the sample was undergoing reduction. During the analysis of IdeS digests, the developed method exhibited the separation of the different fragments generated from the limited digestion with the possibility to distinguish lysine variants. In addition, the same method was applied to analyze mAbs stability samples treated with IdeS followed by reduction. Results obtained for sample experiencing deamidation demonstrated the separation of the Fd fragment bearing a succinimide intermediate on the asparagine of interest therefore revealing the potential of CZE-ESI-MS for the middle-up characterization of therapeutic mAbs [108]. 

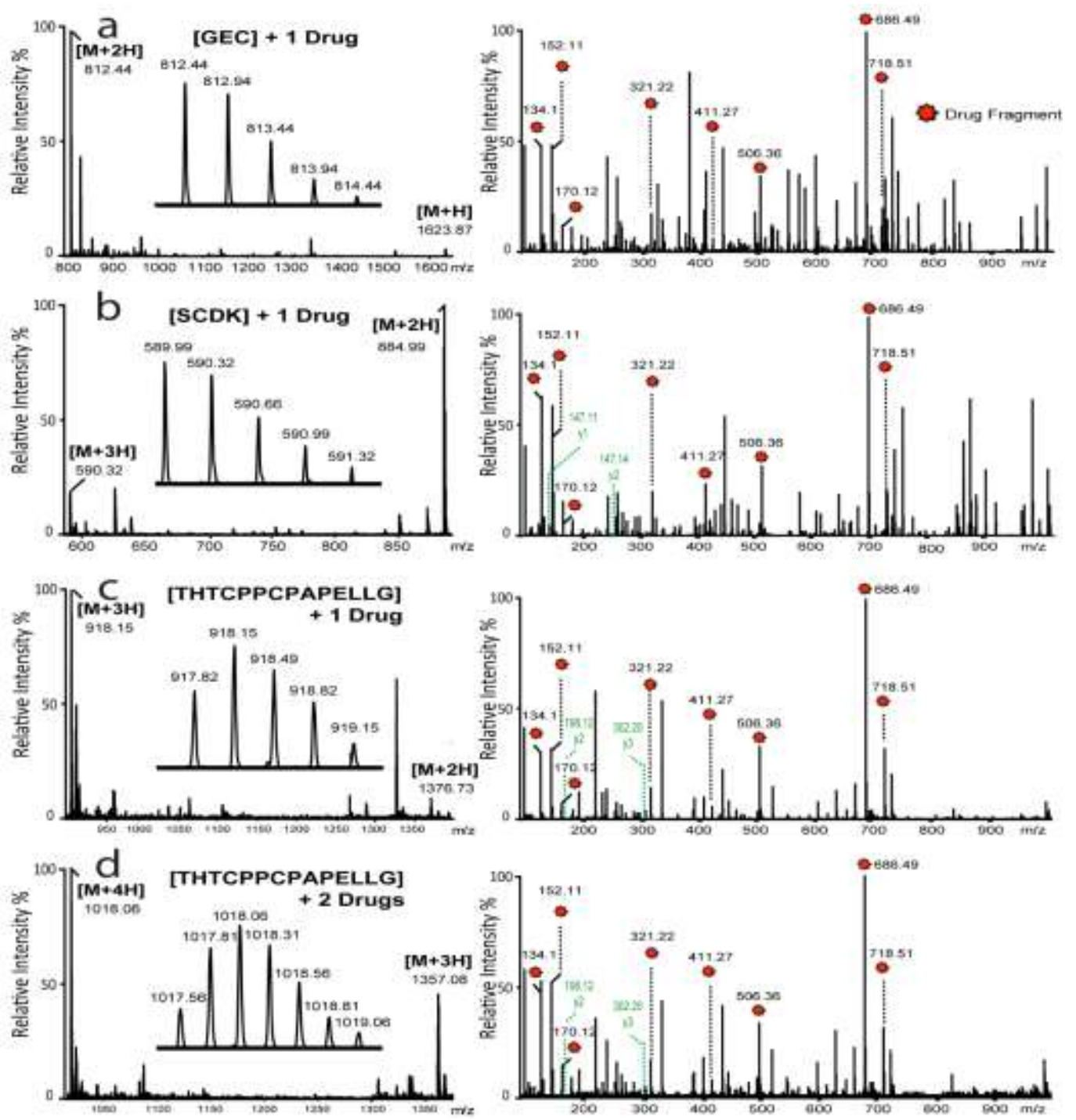

Figure 6. MS and MS/MS spectra of drug-loaded peptides. (a) [GEC]z + 1 payload, (b) [SCDK] +1 payload, (c) [THTCPPCPAPELLG] + 1 payload and (d) [THTCPPCPAPELLG] + 2 payloads. Reprinted from [111]. Copyright (2016) Elsevier.

\subsubsection{Intact analysis}

In depth MS analysis of intact mAbs remains one of the major challenge in the context of analytical characterization of therapeutic mAbs and their related products. CE appears as a technique with significant potential for the characterization of intact mAbs in concomitance with MS due to its separation principle enabling migration of intact proteins. Implementation of CZE-MALDI-MS method developed by Biacchi et al emphasized the possibility to separate intact charge variants of trastuzumab followed by MS identification [92]. Regarding CZE-ESI-MS, Han and coworkers detailed a method for the analysis of intact IgG1. Using PNGase F treated samples, they demonstrated the separation and successful identification of free LC contained in IgG1 reference material [108]. Another 
research of interest was reported by Redman et al. They described the preparation of a microchip CZE-nanoESIMS system enabling the analysis of intact infliximab and showed that lysine variants could be separated and characterized (Figure 5). In addition the system was applied to a IgG1 drug conjugate, their findings proved the possibility to distinguish non conjugated species as well as mono and di-conjugated IgG [109]. Recently, the same research group used this microchip interface for the characterization of intact ADCs. Results reported show the separation of the charge variants generated from $\mathrm{N}$-terminal pyroglutamic acid formation and decarboxylation for the unconjugated mAb. Additionally, ADC analysis demonstrated the separation of species exhibiting different number of conjugated drugs and the ability to determine antibody-drug ratio (DAR) values in agreement to with ESI-MS infusion and imaging CE analysis [110]. The introduction of ADCs is adding a layer of complexity, compared to conventional mAbs, regarding analytical characterization. To address the complexity originating from these modified proteins, Said and coworkers developed an analytical methodology combining ADCs analysis on the intact, middle-up and amino acid sequence level [111]. This methodology, alongside to comprehensive peptide backbone characterization, enables to determine the different species generated from the conjugation reaction and locate the position of the drug on the amino acid sequence (Figure 6). From a general point of view, characterization of intact $\mathrm{mAbs}$ and their related format using CE-MS analysis is currently generating great expectations therefore driving research into intensive development which may presage the introduction of innovative application in the near future

\section{CONCLUSION}

In the past decade, several hundreds of papers have been published on analytical and structural characterization of mAbs and related products using different strategies as chromatography, electrophoresis, and mass spectrometry. As shown is this review, CE presents some clear benefits as high resolution separation, and miniaturized format to be widely applied to the analysis of biopharmaceuticals. CE is a technique fully suitable for the separation of proteins at different levels. CGE, ClEF, iclEF and CZE methods have been particularly relevant for the characterization of size and charge variants of intact and reduced mAbs, while CE-MS appears to be a crucial analytical tool to assess the primary structure of mAbs in providing information about amino acid sequence, PTMs or degradations as oxidation, deamidation, $\mathrm{N}$-terminal pyroglutamate formation, glycosylation, sialylation or C-terminal lysine truncation. These methods are widely applied during the process development and the quality control of the drug. The robustness of some CE-based methods as CGE, CIEF, icIEF and CZE have been assessed by different inter-laboratory studies for the majority managed by independent biopharmaceutical companies $[64,65,80]$. The uniformity of protocols and the assessment of reproducibility and robustness make CE a reference method applied routinely for lot consistency, purity and stability in quality control laboratories of biopharmaceutical companies. 


\section{Acknowledgments}

The authors would like also to express their gratitude to Dr. M. Biacchi (Laboratoire de Biologie Biochimie Moléculaire, CHU Nancy), Dr. E. Wagner-Rousset, MC. Janin-Bussat and O. Colas (Centre d'Immunologie Pierre Fabre, St Julien en Genevois, France) for helpful discussions. This work was supported by the CNRS (UMR 7140) and the University of Strasbourg.

\section{References}

[1] J.N. Arnold, M.R. Wormald, R.B. Sim, P.M. Rudd, R.A. Dwek, The impact of glycosylation on the biological function and structure of human immunoglobulins, Annu. Rev. Immunol. 25 (2007) 21-50.

[2] Z.Q. Zhang, H. Pan, X.Y. Chen, Mass spectrometry for structural characterization of therapeutic antibodies, Mass Spectrom. Rev. 28 (2009) 147-176.

[3] A. Beck, J.M. Reichert, Approval of the first biosimilar antibodies in Europe A major landmark for the biopharmaceutical industry, mAbs 5 (2013) 621-623.

[4] M. McCamish, G. Woollett, The Continuum of Comparability Extends to Biosimilarity: How Much Is Enough and What Clinical Data Are Necessary?, Clin. Pharmacol. Ther. 93 (2013) 315-317.

[5] A. Beck, Biosimilar, biobetter and next generation therapeutic antibodies, mAbs 3 (2011) 107-110.

[6] A. Beck, J.M. Reichert, Marketing approval of mogamulizumab A triumph for glyco-engineering, mAbs 4 (2012) 419-425.

[7] A. Beck, J.M. Reichert, Therapeutic Fc-fusion proteins and peptides as successful alternatives to antibodies, mAbs 3 (2011) 415-416.

[8] A. Beck, H. Diemer, D. Ayoub, F. Debaene, E. Wagner-Rousset, C. Carapito, A. Van Dorsselaer, S. Sanglier-Cianferani, Analytical characterization of biosimilar antibodies and Fc-fusion proteins, TrAC, Trends Anal. Chem. 48 (2013) 81-95.

[9] A. Beck, J.M. Reichert, Antibody-drug conjugates, mAbs 6 (2014) 15-17.

[10] A. Beck, J.M. Reichert, The amazing, multipurpose antibody, mAbs 3 (2011) 221-222.

[11] B. DiPaolo, A. Pennetti, L. Nugent, K. Venkat, Monitoring impurities in biopharmaceuticals produced by recombinant technology, Pharm. Sci. Tech. Today 2 (1999) 70-82.

[12] N.J. Thompson, L.J.A. Hendriks, J. de Kruif, M. Throsby, A.J.R. Heck, Complex mixtures of antibodies generated from a single production qualitatively and quantitatively evaluated by native Orbitrap mass spectrometry, mAbs 6 (2014) 197-203.

[13] S. Fekete, D. Guillarme, P. Sandra, K. Sandra, Chromatographic, Electrophoretic, and Mass Spectrometric Methods for the Analytical Characterization of Protein Biopharmaceuticals, Anal. Chem. 88(1) (2015) 480-507.

[14] C.E. Doneanu, A. Xenopoulos, K. Fadgen, J. Murphy, S.J. Skilton, H. Prentice, M. Stapels, W.B. Chen, Analysis of host-cell proteins in biotherapeutic proteins by comprehensive online two-dimensional liquid chromatography/mass spectrometry, mAbs 4 (2012) 24-44.

[15] A. Beck, E. Wagner-Rousset, D. Ayoub, A. Van Dorsselaer, S. Sanglier-Cianférani, Characterization of Therapeutic Antibodies and Related Products, Anal. Chem. 85 (2013) 715-736.

[16] A. Beck, E. Wagner-Rousset, M.C. Bussat, M. Lokteff, C. Klinguer-Hamour, J.F. Haeuw, L. Goetsch, T. Wurch, A. Van Dorsselaer, N. Corvaia, Trends in Glycosylation, Glycoanalysis and Glycoengineering of Therapeutic Antibodies and Fc-Fusion Proteins, Curr. Pharm. Biotech. 9 (2008) 482-501.

[17] J. Vlasak, M.C. Bussat, S.Y. Wang, E. Wagner-Rousset, M. Schaefer, C. Klinguer-Hamour, M. Kirchmeier, N. Corvaia, R. Ionescu, A. Beck, Identification and characterization of asparagine deamidation in the light chain CDR1 of a humanized IgG1 antibody, Anal. Biochem. 392 (2009) 145-154.

[18] S. Hu, N.J. Dovichi, Capillary Electrophoresis for the Analysis of Biopolymers, Anal. Chem. 74 (2002) 2833-2850.

[19] Z. Zhu, J.J. Lu, S. Liu, Protein separation by capillary gel electrophoresis: A review, Anal. Chim. Acta, 709 (2012) 21-31.

[20] A. Wakankar, Y. Chen, Y. Gokarn, F.S. Jacobson, Analytical methods for physicochemical characterization of antibody drug conjugates, mAbs 3 (2011) 161-172.

[21] D.C. Simpson, R.D. Smith, Combining capillary electrophoresis with mass spectrometry for applications in proteomics, Electrophoresis 26 (2005) 1291-1305.

[22] M. Pioch, S.C. Bunz, C. Neususs, Capillary electrophoresis/mass spectrometry relevant to pharmaceutical and biotechnological applications, Electrophoresis 33 (2012) 1517-1530. 
[23] E. Tamizi, A. Jouyban, The potential of the capillary electrophoresis techniques for quality control of biopharmaceuticalsA review, Electrophoresis 36 (2015) 831-858.

[24] S.S. Zhao, D.D.Y. Chen, Applications of capillary electrophoresis in characterizing recombinant protein therapeutics, Electrophoresis 35 (2014) 96-108.

[25] S. Fekete, A.L. Gassner, S. Rudaz, J. Schappler, D. Guillarme, Analytical strategies for the characterization of therapeutic monoclonal antibodies, TrAC, Trends Anal. Chem. 42 (2013) 74-83.

[26] S. El Deeb, H. Watzig, D. Abd El-Hady, Capillary electrophoresis to investigate biopharmaceuticals and pharmaceuticallyrelevant binding properties, TrAC, Trends Anal. Chem. 48 (2013) 112-131.

[27] S. El Deeb, H. Watzig, D. Abd El-Hady, H.M. Albishri, C. Sanger-van de Griend, G.K.E. Scriba, Recent advances in capillary electrophoretic migration techniques for pharmaceutical analysis, Electrophoresis 35 (2014) 170-189.

[28] J.S. Creamer, N.J. Oborny, S.M. Lunte, Recent advances in the analysis of therapeutic proteins by capillary and microchip electrophoresis, Anal. Meth. 6 (2014) 5427-5449.

[29] V. Dotz, R. Haselberg, A. Shubhakar, R.P. Kozak, D. Falck, Y. Rombouts, D. Reusch, G.W. Somsen, D.L. Fernandes, M. Wuhrer, Mass spectrometry for glycosylation analysis of biopharmaceuticals, TrAC, Trends Anal. Chem. 73 (2015) 1-9.

[30] Z. Szabo, A.s. Guttman, J. Bones, B.L. Karger, Rapid High-Resolution Characterization of Functionally Important Monoclonal AntibodyN-Glycans by Capillary Electrophoresis, Anal. Chem. 83 (2011) 5329-5336.

[31] B.T. Cooper, R.D. Sanzgiri, S.B. Maxey, Probing the conformational behavior of a monoclonal antibody with surfactant affinity capillary electrophoresis (SurfACE), Analyst 137 (2012) 5777-5784.

[32] S.C. Bunz, E. Rapp, C. Neususs, Capillary Electrophoresis/Mass Spectrometry of APTS-Labeled Glycans for the Identification of Unknown Glycan Species in Capillary Electrophoresis/Laser-Induced Fluorescence Systems, Anal. Chem. 85 (2013) 10218-10224.

[33] M. Hamm, Y. Wang, R.R. Rustandi, Characteization of N-Linked Glycosylation in a Monoclonal antibody Produced in NS0 Cells Using Capillary Electrophoresis with Laser Induced Fluorescence Detection, Pharmaceuticals 6 (2013) $393-406$.

[34] Á. Szekrényes, S.S. Park, M. Santos, C. Lew, A. Jones, T. Haxo, M. Kimzey, S. Pourkaveh, Z. Szabó, Z. Sosic, P. Feng, C. Váradi, F. de I'Escaille, J.-B. Falmagne, P. Sejwal, T. Niedringhaus, D. Michels, G. Freckleton, M. Hamm, A. Manuilov, M. Schwartz, J.-K. Luo, J. van Dyck, P.-K. Leung, M. Olajos, Y. Gu, K. Gao, W. Wang, J. Wegstein, S. Tep, A. Guttman, Multi-Site N-glycan mapping study 1: Capillary electrophoresis - laser induced fluorescence, mAbs 8(1) (2016) 56-64.

[35] D. Reusch, M. Haberger, B. Maier, M. Maier, R. Kloseck, B. Zimmermann, M. Hook, Z. Szabo, S. Tep, J. Wegstein, N. Alt, P. Bulau, M. Wuhrer, Comparison of methods for the analysis of therapeutic immunoglobulin G Fc-glycosylation profiles-Part 1: Separation-based methods, mAbs, 7 (2015) 167-179.

[36] C. Varadi, C. Lew, A. Guttman, Rapid Magnetic Bead Based Sample Preparation for Automated and High Throughput NGlycan Analysis of Therapeutic Antibodies, Anal. Chem. 86 (2014) 5682-5687.

[37] T. Wang, S. Fodor, S. Hapuarachchi, X.G. Jiang, K. Chen, I. Apostol, G. Huang, Analysis and characterization of aggregation of a therapeutic Fc-fusion protein, J. Pharm. Biomed. Anal. 72 (2013) 59-64.

[38] E. Maeda, S. Kita, M. Kinoshita, K. Urakami, T. Hayakawa, K. Kakehi, Analysis of Nonhuman N-Glycans as the Minor Constituents in Recombinant Monoclonal Antibody Pharmaceuticals, Anal. Chem. 84 (2012) 2373-2379.

[39] G. Soman, A.T. Kallarakal, D. Michiel, X.Y. Yang, N. Saptharishi, H.G. Jiang, S. Giardina, J. Gilly, G. Mitra, Analytical characterization of ch14.18 A mouse-human chimeric disialoganglioside-specific therapeutic antibody, mAbs 4 (2012) 84-100. [40] Z. Szabo, A. Guttman, J. Bones, R.L. Shand, D. Meh, B.L. Karger, Ultrasensitive Capillary Electrophoretic Analysis of Potentially Immunogenic Carbohydrate Residues in Biologics: Galactose-alpha-1,3-Galactose Containing Oligosaccharides, Mol. Pharmacol. 9 (2012) 1612-1619.

[41] Y. Yagi, K. Kakehi, T. Hayakawa, Y. Ohyama, S. Suzuki, Specific detection of N-glycolylneuraminic acid and Gal alpha 1-3Gal epitopes of therapeutic antibodies by partial-filling capillary electrophoresis, Anal. Biochem. 431 (2012) 120-126.

[42] Y. Yagi, S. Yamamoto, K. Kakehi, T. Hayakawa, Y. Ohyama, S. Suzuki, Application of partial-filling capillary electrophoresis using lectins and glycosidases for the characterization of oligosaccharides in a therapeutic antibody, Electrophoresis 32 (2011) 2979-2985.

[43] C. Wacker, C.N. Berger, P. Girard, R. Meier, Glycosylation profiles of therapeutic antibody pharmaceuticals, Eur. J. Pharm. Biopharm. 79 (2011) 503-507.

[44] D.A. Michels, L.J. Brady, A. Guo, A. Balland, Fluorescent Derivatization Method of Proteins for Characterization by Capillary Electrophoresis- Sodium Dodecyl Sulfate with Laser-Induced Fluorescence Detection, Anal. Chem. 79 (2007) 59635971.

[45] D.A. Michels, M. Parker, O. Salas-Solano, Quantitative impurity analysis of monoclonal antibody size heterogeneity by CELIF: Example of development and validation through a quality-by-design framework, Electrophoresis 33 (2012) 815-826.

[46] Y. Shi, Z. Li, J. Lin, Advantages of CE-SDS over SDS-PAGE in mAb purity analysis, Analytical Methods, 4 (2012) $1637-1642$. 
[47] J. Visser, I. Feuerstein, T. Stangler, T. Schmiederer, C. Fritsch, M. Schiestl, Physicochemical and Functional Comparability Between the Proposed Biosimilar Rituximab GP2013 and Originator Rituximab, Biodrugs 27 (2013) 495-507.

[48] Z.W.K. Glover, L. Gennaro, S. Yadav, B. Demeule, P.Y. Wong, A. Sreedhara, Compatibility and stability of pertuzumab and trastuzumab admixtures in i.v. infusion bags for coadministration, J. Pharm. Sci. 102 (2013) 794-812.

[49] S. Cherkaoui, T. Bettinger, M. Hauwel, S. Navetat, E. Allémann, M. Schneider, Tracking of antibody reduction fragments by capillary gel electrophoresis during the coupling to microparticles surface, J. Pharm. Biomed. Anal. 53 (2010) 172-178.

[50] S. Yin, C.V. Pastuskovas, L.A. Khawli, J.T. Stults, Characterization of Therapeutic Monoclonal Antibodies Reveals Differences Between In Vitro and In Vivo Time-Course Studies, Pharm. Res. 30 (2013) 167-178.

[51] A. Szekely, A. Szekrenyes, M. Kerekgyarto, A. Balogh, J. Kadas, J. Lazar, A. Guttman, I. Kurucz, L. Takacs, Multicapillary SDSgel electrophoresis for the analysis of fluorescently labeled mAb preparations: A high through put quality control process for the production of QuantiPlasma and PlasmaScan mAb libraries, Electrophoresis 35 (2014) 2155-2162.

[52] Y. Yagi, K. Kakehi, T. Hayakawa, S. Suzuki, Application of Microchip Electrophoresis Sodium Dodecyl Sulfate for the Evaluation of Change of Degradation Species of Therapeutic Antibodies in Stability Testing, Anal. Sci. 30 (2014) 483-488.

[53] D. Reusch, M. Haberger, T. Kailich, A.K. Heidenreich, M. Kampe, P. Bulau, M. Wuhrer, High-throughput glycosylation analysis of therapeutic immunoglobulin $\mathrm{G}$ by capillary gel electrophoresis using a DNA analyzer, mAbs 6 (2014) 185-196.

[54] L.N. Le, J.M.R. Moore, J. Ouyang, X.Y. Chen, M.D.H. Nguyen, W.J. Galush, Profiling Antibody Drug Conjugate Positional Isomers: A System-of-Equations Approach, Anal. Chem. 84 (2012) 7479-7486.

[55] S. Hapuarachchi, S. Fodor, I. Apostol, G. Huang, Use of capillary electrophoresis-sodium dodecyl sulfate to monitor disulfide scrambled forms of an Fc fusion protein during purification process, Anal. Biochem. 414 (2011) 187-195.

[56] S. Hjerten, M.D. Zhu, Adaptation of the equipement for high-performance electrophoresis to isoelectric-focusing, J. Chromatogr. 346 (1985) 265-270.

[57] D.A. Michels, A.W. Tu, W. McElroy, D. Voehringer, O. Salas-Solano, Charge Heterogeneity of Monoclonal Antibodies by Multiplexed Imaged Capillary Isoelectric Focusing Immunoassay with Chemiluminescence Detection, Anal. Chem. 84 (2012) 5380-5386.

[58] G. Zhu, L. Sun, R. Wojcik, D. Kernaghan, J.B. McGivney Iv, N.J. Dovichi, A rapid clEF-ESI-MS/MS method for host cell protein analysis of a recombinant human monoclonal antibody, Talanta, 98 (2012) 253-256.

[59] J. Lin, Q.Q. Tan, S.X. Wang, A high-resolution capillary isoelectric focusing method for the determination of therapeutic recombinant monoclonal antibody, J. Sep. Sci. 34 (2011) 1696-1702.

[60] R. Bonn, S. Rampal, T. Rae, J. Fishpaugh, CIEF method optimization: Development of robust and reproducible protein reagent characterization in the clinical immunodiagnostic industry, Electrophoresis 34 (2013) 825-832.

[61] J.Z. Cao, W. Sun, F.F. Gong, W.H. Liu, Charge profiling and stability testing of biosimilar by capillary isoelectric focusing, Electrophoresis 35 (2014) 1461-1468.

[62] D. Suba, Z. Urbanyi, A. Salgo, Capillary isoelectric focusing method development and validation for investigation of recombinant therapeutic monoclonal antibody, J. Pharm. Biomed. Anal. 114 (2015) 53-61.

[63] C. Raymond, A. Robotham, M. Spearman, M. Butler, J. Kelly, Y. Durocher, Production of alpha 2,6-sialylated IgG1 in CHO cells, mAbs 7 (2015) 571-583.

[64] O. Salas-Solano, K. Babu, S.S. Park, X.F. Zhang, L. Zhang, Z. Sosic, B. Boumajny, M. Zeng, K.C. Cheng, A. Reed-Bogan, S. Cummins-Bitz, D.A. Michels, M. Parker, P. Bonasia, M.F. Hong, S. Cook, M. Ruesch, D. Lamb, D. Bolyan, S. Kiessig, D. Allender, B. Nunnally, Intercompany Study to Evaluate the Robustness of Capillary Isoelectric Focusing Technology for the Analysis of Monoclonal Antibodies, Chromatographia 73 (2011) 1137-1144.

[65] O. Salas-Solano, B. Kennel, S.S. Park, K. Roby, Z. Sosic, B. Boumajny, S. Free, A. Reed-Bogan, D. Michels, W. McElroy, P. Bonasia, M.F. Hong, X.P. He, M. Ruesch, F. Moffatt, S. Kiessig, B. Nunnally, Robustness of iCIEF methodology for the analysis of monoclonal antibodies: An interlaboratory study, J. Sep. Sci. 35 (2012) 3124-3129.

[66] E.T.J. van den Bremer, F.J. Beurskens, M. Voorhorst, P.J. Engelberts, R.N. de Jong, B.G. van der Boom, E.M. Cook, M.A. Lindorfer, R.P. Taylor, P.H.C. van Berkel, P.W.H.I. Parren, Human IgG is produced in a pro-form that requires clipping of Cterminal lysines for maximal complement activation, mAbs 7 (2015) 672-680.

[67] C.D. Meert, L.J. Brady, A. Guo, A. Balland, Characterization of Antibody Charge Heterogeneity Resolved by Preparative Immobilized pH Gradients, Anal. Chem. 82 (2010) 3510-3518.

[68] O.O. Dada, N. Jaya, J. Valliere-Douglass, O. Salas-Solano, Characterization of acidic and basic variants of IgG1 therapeutic monoclonal antibodies based on non-denaturing IEF fractionation, Electrophoresis 36 (2015) 2695-2702.

[69] M. Kinoshita, Y. Nakatsuji, S. Suzuki, T. Hayakawa, K. Kakehi, Quality assurance of monoclonal antibody pharmaceuticals based on their charge variants using microchip isoelectric focusing method, J. Chromatogr. A, 1309 (2013) 76-83.

[70] C.L. Anderson, Y. Wang, R.R. Rustandi, Applications of imaged capillary isoelectric focussing technique in development of biopharmaceutical glycoprotein-based products, Electrophoresis 33 (2012) 1538-1544. 
[71] Z.G. Wu, P. Zhou, X.X. Li, H. Wang, D.L. Luo, H.Y. Qiao, X. Ke, J. Huang, Structural Characterization of a Recombinant Fusion Protein by Instrumental Analysis and Molecular Modeling, Plos One 8 (2013).

[72] J.F. Valliere-Douglass, P. Lewis, O. Salas-Solano, S. Jiang, Solid-State mAbs and ADCs Subjected to Heat-Stress Stability Conditions can be Covalently Modified with Buffer and Excipient Molecules, J. Pharm. Sci. 104 (2015) 652-665.

[73] E. Maeda, K. Urakami, K. Shimura, M. Kinoshita, K. Kakehi, Charge heterogeneity of a therapeutic monoclonal antibody conjugated with a cytotoxic antitumor antibiotic, calicheamicin, J. Chromatogr. A 1217 (2010) 7164-7171.

[74] D. Michels, O. Salas-Solano, C. Felten, Imaged Capillary Isoelectric Focusing for Charge-Variant Analysis of Biopharmaceuticals, BioProcess Int. 9 (2011) 48-53.

[75] S. Hjerten, High-performance electrophoresis - the electrophoretic conterpart of high-performance liquidchromatography, J. Chromatogr. 270 (1983) 1-6.

[76] V. Dolník, Wall coating for capillary electrophoresis on microchips, Electrophoresis 25 (2004) 3589-3601.

[77] A.L. Gassner, S. Rudaz, J. Schappler, Static coatings for the analysis of intact monoclonal antibody drugs by capillary zone electrophoresis, Electrophoresis 34 (2013) 2718-2724.

[78] Y. He, N.A. Lacher, W. Hou, Q. Wang, C. Isele, J. Starkey, M. Ruesch, Analysis of Identity, Charge Variants, and Disulfide Isomers of Monoclonal Antibodies with Capillary Zone Electrophoresis in an Uncoated Capillary Column, Anal. Chem. 82 (2010) 3222-3230.

[79] Y. He, C. Isele, W. Hou, M. Ruesch, Rapid analysis of charge variants of monoclonal antibodies with capillary zone electrophoresis in dynamically coated fused-silica capillary, J. Sep. Sci. 34 (2011) 548-555.

[80] B. Moritz, V. Schnaible, S. Kiessig, A. Heyne, M. Wild, C. Finkler, S. Christians, K. Mueller, L. Zhang, K. Furuya, M. Hassel, M. Hamm, R. Rustandi, Y. He, O.S. Solano, C. Whitmore, S.A. Park, D. Hansen, M. Santos, M. Lies, Evaluation of capillary zone electrophoresis for charge heterogeneity testing of monoclonal antibodies, J. Chromatogr. B 983-984 (2015) 101-110.

[81] Y. Shi, Z. Li, Y.B. Qiao, J. Lin, Development and validation of a rapid capillary zone electrophoresis method for determining charge variants of mAb, J. Chromatogr. B 906 (2012) 63-68.

[82] H.L. Han, E. Livingston, X.Y. Chen, High Throughput Profiling of Charge Heterogeneity in Antibodies by Microchip Electrophoresis, Anal. Chem. 83 (2011) 8184-8191.

[83] C.E. Espinosa-de la Garza, F.C. Perdomo-Abundez, J. Padilla-Calderon, J.M. Uribe-Wiechers, N.O. Perez, L.F. Flores-Ortiz, E. Medina-Rivero, Analysis of recombinant monoclonal antibodies by capillary zone electrophoresis, Electrophoresis 34 (2013) 1133-1140.

[84] T.D. Wheeler, J.L. Sun, S. Pleiner, H. Geier, P. Dobberthien, J. Studts, R. Singh, B. Fathollahi, Microchip Zone Electrophoresis for High-Throughput Analysis of Monoclonal Antibody Charge Variants, Anal. Chem. 86 (2014) 5416-5424.

[85] B. Antes, P. Oberkleiner, A. Nechansky, O.H.J. Szolar, Qualification of a microfluidics-based electrophoretic method for impurity testing of monoclonal antibodies, J. Pharm. Biomed. Anal. 51 (2010) 743-749.

[86] E. Jaccoulet, C. Smadja, P. Prognon, M. Taverna, Capillary electrophoresis for rapid identification of monoclonal antibodies for routine application in hospital, Electrophoresis 36 (2015) 2050-2056.

[87] J.A. Olivares, N.T. Nguyen, C.R. Yonker, R.D. Smith, Online mass-spectrometric detection for capillary zone electrophoresis, Anal. Chem. 59 (1987) 1230-1232.

[88] J.M. Busnel, B. Schoenmaker, R. Ramautar, A. Carrasco-Pancorbo, C. Ratnayake, J.S. Feitelson, J.D. Chapman, A.M. Deelder, O.A. Mayboroda, High Capacity Capillary Electrophoresis-Electrospray Ionization Mass Spectrometry: Coupling a Porous Sheathless Interface with Transient-Isotachophoresis, Anal. Chem. 82 (2010) 9476-9483.

[89] R. Wojcik, O.O. Dada, M. Sadilek, N.J. Dovichi, Simplified capillary electrophoresis nanospray sheath-flow interface for high efficiency and sensitive peptide analysis, Rapid Commun. Mass Sp. 24 (2010) 2554-2560.

[90] X.F. Zhong, E.J. Maxwell, D.D.Y. Chen, Mass Transport in a Micro Flow-Through Vial of a Junction-at-the-Tip Capillary Electrophoresis-Mass Spectrometry Interface, Anal. Chem. 83 (2011) 4916-4923.

[91] K. Kleparnik, Recent advances in combination of capillary electrophoresis with mass spectrometry: Methodology and theory, Electrophoresis 36 (2015) 159-178.

[92] M. Biacchi, R. Bhajun, N. Saïd, A. Beck, Y.N. François, E. Leize-Wagner, Analysis of monoclonal antibody by a novel CEUV/MALDI-MS interface, Electrophoresis 35 (2014) 2986-2995.

[93] L.A. Gennaro, O. Salas-Solano, S. Ma, Capillary electrophoresis-mass spectrometry as a characterization tool for therapeutic proteins, Anal. Biochem. 355 (2006) 249-258.

[94] C.D. Whitmore, L.A. Gennaro, Capillary electrophoresis-mass spectrometry methods for tryptic peptide mapping of therapeutic antibodies, Electrophoresis 33 (2012) 1550-1556.

[95] R. Gahoual, A. Burr, J.M. Busnel, L. Kuhn, P. Hammann, A. Beck, Y.N. Francois, E. Leize-Wagner, Rapid and multi-level characterization of trastuzumab using sheathless capillary electrophoresis-tandem mass spectrometry, mAbs 5 (2013) 479 490. 
[96] R. Gahoual, J.-M. Busnel, A. Beck, Y.-N. François, E. Leize-Wagner, Full Antibody Primary Structure and Microvariant Characterization in a Single Injection Using Transient Isotachophoresis and Sheathless Capillary Electrophoresis-Tandem Mass Spectrometry, Anal. Chem. 86 (2014) 9074-9081.

[97] R. Gahoual, A. Beck, Y.N. Francois, E. Leize-Wagner, Independent highly sensitive characterization of asparagine deamidation and aspartic acid isomerization by sheathless CZE-ESI-MS/MS, J. Mass Spectrom. 51 (2016) 150-158.

[98] C. Lew, J.-L. Gallegos-Perez, B. Fonslow, M. Lies, A. Guttman, Rapid Level-3 Characterization of Therapeutic Antibodies by Capillary Electrophoresis Electrospray Ionization Mass Spectrometry, J. Chrom. Sci. 53 (2015) 443-449.

[99] R. Gahoual, M. Biacchi, J. Chicher, L. Kuhn, P. Hammann, A. Beck, E. Leize-Wagner, Y.N. Francois, Monoclonal antibodies biosimilarity assessment using transient isotachophoresis capillary zone electrophoresis-tandem mass spectrometry, mAbs 6 (2014) 1464-1473.

[100] L.A. Gennaro, O. Salas-Solano, On-line CE-LIF-MS technology for the direct characterization of N-linked glycans from therapeutic antibodies, Anal. Chem. 80 (2008) 3838-3845.

[101] S.C. Bunz, F. Cutillo, C. Neususs, Analysis of native and APTS-labeled N-glycans by capillary electrophoresis/time-of-flight mass spectrometry, Anal. Bioanal. Chem. 405 (2013) 8277-8284.

[102] R. Gahoual, M. Biacchi, J.M. Busnel, A. Beck, Y.F. Francois, E. Leize-Wagner, Comprehensive Multilevel Characterization of Biologics Using Sheathless Capillary Electrophoresis Hyphenated to tandem Mass Spectrometry, LC GC N. Am. 13 (2015) 815.

[103] B. Vincents, U. von Pawel-Rammingen, L. Bjorck, M. Abrahamson, Enzymatic characterization of the streptococcal endopeptidase, IdeS, reveals that it is a cysteine protease with strict specificity for IgG cleavage due to exosite binding, Biochemistry, 43 (2004) 15540-15549.

[104] G. Chevreux, N. Tilly, N. Bihoreau, Fast analysis of recombinant monoclonal antibodies using IdeS proteolytic digestion and electrospray mass spectrometry, Anal. Biochem. 415 (2011) 212-214.

[105] M. Biacchi, R. Gahoual, N. Said, A. Beck, E. Leize-Wagner, Y.-N. François, Glycoform Separation and Characterization of Cetuximab Variants by Middle-up Off-Line Capillary Zone Electrophoresis-UV/Electrospray Ionization-MS, Anal. Chem. 87 (2015) 6240-6250.

[106] Y.-N. François, M. Biacchi, N. Said, C. Renard, A. Beck, R. Gahoual, E. Leize-Wagner, Characterization of Cetuximab Fc/2 aggregates by Off-line CZE-MS, Anal. Chim. Acta 908 (2016) 168-176.

[107] Y. Zhao, L. Sun, M.D. Knierman, N.J. Dovichi, Fast separation and analysis of reduced monoclonal antibodies with capillary zone electrophoresis coupled to mass spectrometry, Talanta 148 (2016) 529-533.

[108] M. Han, B.M. Rock, J.T. Pearson, D.A. Rock, Intact Mass Analysis of Monoclonal Antibodies by Capillary ElectrophoresisMass Spectrometry, J. Chrom. B 1011 (2016) 24-32.

[109] E.A. Redman, N.G. Batz, J.S. Mellors, J.M. Ramsey, Integrated Microfluidic Capillary Electrophoresis-Electrospray Ionization Devices with Online MS Detection for the Separation and Characterization of Intact Monoclonal Antibody Variants, Analy. Chem. 87 (2015) 2264-2272.

[110] E.A. Redman, J.S. Mellors, J.A. Starkey, J.M. Ramsey, Characterization of Intact Antibody Drug Conjugate Variants Using Microfluidic Capillary Electrophoresis-Mass Spectrometry, Anal. Chem. 88 (2016) 2220-2226.

[111] N. Said, R. Gahoual, L. Kuhn, A. Beck, Y.-N. François, E. Leize-Wagner, Structural characterization of antibody drug conjugate by a combination of intact, middle-up and bottom-up techniques using sheathless capillary electrophoresis Tandem mass spectrometry as nanoESI infusion platform and separation method, Anal. Chim. Acta 918 (2016) 50-59.

[112] Y. Wang, M. Santos, A. Guttman, Comparative core fucosylation analysis of some major therapeutic antibody N-glycans by direct infusion ESI-MS and CE-LIF detection, J. Sep. Sci. 36 (2013) 2862-2867.

[113] C. Cianciulli, T. Hahne, H. Watzig, Capillary gel electrophoresis for precise protein quantitation, Electrophoresis 33 (2012) 3276-3280.

[114] D.H. Na, E.J. Park, M.S. Kim, H.S. Lee, K.C. Lee, Application of Sodium Dodecyl Sulfate-Capillary Gel Electrophoresis to the Characterization of Ricin A-Chain Immunotoxins, Chromatographia 75 (2012) 679-683.

[115] A. Szekrenyes, U. Roth, M. Kerekgyarto, A. Szekely, I. Kurucz, K. Kowalewski, A. Guttman, High-throughput analysis of therapeutic and diagnostic monoclonal antibodies by multicapillary SDS gel electrophoresis in conjunction with covalent fluorescent labeling, Anal. Bioanal. Chem. 404 (2012) 1485-1494.

[116] T.J. Kamerzell, M.G. Li, S. Arora, J.A. Ji, Y.J. Wang, The Relative Rate of Immunoglobulin Gamma 1 Fragmentation, J. Pharm. Sci. 100 (2011) 1341-1349.

[117] T. Kaschak, D. Boyd, B. Yan, Characterization of glycation in an IgG1 by capillary electrophoresis sodium dodecyl sulfate and mass spectrometry, Anal. Biochem. 417 (2011) 256-263.

[118] R.R. Rustandi, Y. Wang, Use of CE-SDS gel for characterization of monoclonal antibody hinge region clipping due to copper and high pH stress, Electrophoresis 32 (2011) 3078-3084. 
[119] R.B. Kotia, A.R. Raghani, Analysis of monoclonal antibody product heterogeneity resulting from alternate cleavage sites of signal peptide, Anal. Biochem. 399 (2010) 190-195.

[120] N.A. Lacher, R.K. Roberts, Y. He, H. Cargill, K.M. Kearns, H. Holovics, M.N. Ruesch, Development, validation, and implementation of capillary gel electrophoresis as a replacement for SDS-PAGE for purity analysis of IgG2 mAbs, J. Sep. Sci. 33 (2010) 218-227.

[121] N.A. Lacher, O. Wang, R.K. Roberts, H.J. Holovics, S. Aykent, M.R. Schlittler, M.R. Thompson, C.W. Demarest, Development of a capillary gel electrophoresis method for monitoring disulfide isomer heterogeneity in IgG2 antibodies, Electrophoresis 31 (2010) 448-458.

[122] C. Wang, T. Li, Z.X. Wang, F. Feng, H.L. Wang, Quantitative study of stereospecific binding of monoclonal antibody to anti-benzo(a)pyrene diol epoxide-N-2-dG adducts by capillary electrophoresis immunoassay, J. Chromatogr. A 1217 (2010) 2254-2261.

[123] J. Zhang, S. Burman, S. Gunturi, J.P. Foley, Method development and validation of capillary sodium dodecyl sulfate gel electrophoresis for the characterization of a monoclonal antibody, J. Pharm. Biomed. Anal. 53 (2010) 1236-1243.

[124] Y.-Y. Zhao, N. Wang, W.-H. Liu, W.-J. Tao, L.-L. Liu, Z.-D. Shen, Charge Variants of an Avastin Biosimilar Isolation, Characterization, In Vitro Properties and Pharmacokinetics in Rat, PLoS One 11 (2016) 1-13.

[125] R.P. Vanam, M.A. Schneider, M.S. Marlow, Rapid quantitative analysis of monoclonal antibody heavy and light chain charge heterogeneity, mAbs 7 (2015) 1118-1127.

[126] D.Y. Ren, J. Zhang, R. Pritchett, H.B. Liu, J. Kyauk, J. Luo, A. Amanullah, Detection and identification of a serine to arginine sequence variant in a therapeutic monoclonal antibody, J. Chromatogr. B 879 (2011) 2877-2884.

[127] J. Zhang, H. Yip, V. Katta, Identification of isomerization and racemization of aspartate in the Asp-Asp motifs of a therapeutic protein, Anal. Biochem. 410 (2011) 234-243.

[128] C. Lehermayr, H.C. Mahler, K. Mader, S. Fischer, Assessment of Net Charge and Protein-Protein Interactions of Different Monoclonal Antibodies, J. Pharm. Sci. 100 (2011) 2551-2562.

[129] M. Andrasi, G. Lehoczki, Z. Nagy, G. Gyemant, A. Pungor, A. Gaspar, A comparative study of capillary electrophoresis and isothermal titration calorimetry for the determination of binding constant of human serum albumin to monoclonal antibody, Electrophoresis 36 (2015) 1274-1281.

[130] H. Wu, K. Truncali, J. Ritchie, R. Kroe-Barrett, S. Singh, A.S. Robinson, C.J. Roberts, Weak protein interactions and pHand temperature-dependent aggregation of human Fc1, mAbs 7 (2015) 1072-1083.

[131] S.K. Li, M.R. Liddell, H. Wen, Effective electrophoretic mobilities and charges of anti-VEGF proteins determined by capillary zone electrophoresis, J. Pharm.Biomed. Anal. 55 (2011) 603-607.

[132] H. Cai, Y.L. Song, J. Zhang, T. Shi, Y. Fu, R. Li, N. Mussa, Z.J. Li, Optimization of microchip-based electrophoresis for monoclonal antibody product quality analysis revealed needs for extra surfactants during denaturation, J. Pharm. Biomed. Anal. 120 (2016) 46-56.

[133] F.G. Ye, T.Z. Yang, Y. Huang, S.T. Li, S.L. Zhao, Homogeneous immunoassay of cortisol based on microchip electrophoresis with chemiluminescence detection, Anal. Method 5 (2013) 5657-5661.

[134] J. Primack, G.C. Flynn, H. Pan, A high-throughput microchip-based glycan screening assay for antibody cell culture samples, Electrophoresis 32 (2011) 1129-1132.

[135] Y. Huang, S.L. Zhao, M. Shi, Y.M. Liu, Chemiluminescent immunoassay of thyroxine enhanced by microchip electrophoresis, Anal. Biochem. 399 (2010) 72-77.

[136] G. Zhu, L. Sun, J. Heidbrink-Thompson, S. Kuntumalla, H.-y. Lin, C.J. Larkin, J.B.M. Iv, N.J. Dovichi, Capillary zone electrophoresis-tandem mass spectrometry detects low concentration host cell impurities in monoclonal antibodies, Electrophoresis 37 (2015) 616-622.

[137] J.S. Mellors, W.A. Black, A.G. Chambers, J.A. Starkey, N.A. Lacher, J.M. Ramsey, Hybrid Capillary/Microfluidic System for Comprehensive Online Liquid Chromatography-Capillary Electrophoresis-Electrospray Ionization-Mass Spectrometry, Anal. Chem. 85 (2013) 4100-4106. 


\begin{tabular}{|c|c|c|c|c|c|c|}
\hline CE Mode & Detection & Sample & Application & BGE & Cap. coating & Reference \\
\hline CGE & UV $200 \mathrm{~nm}$ & $\operatorname{lgG1}$ & Size heterogeneity of intact $\mathrm{mAb}$ & BC SDS-Mw gel buffer & BFS & [68] \\
\hline CGE & LIF $488 \mathrm{~nm}, 520 \mathrm{~nm}$ & Human IgG & N-Glycan mapping (Interlaboratory) & $\begin{array}{l}\text { Sciex N-CHO carbohy- } \\
\text { drate separation gel buf- } \\
\text { fer }\end{array}$ & Sciex N-CHO & [34] \\
\hline CGE & LIF $488 \mathrm{~nm}, 520 \mathrm{~nm}$ & $\lg G$ & Glycosylation profiling & $\begin{array}{l}\text { carbohydrate separation } \\
\text { buffer and eCaP }{ }^{\mathrm{TM}} \text { DNA } \\
\text { gel } 1000\end{array}$ & eCaP ${ }^{\mathrm{TM}}$ neutral & [35] \\
\hline CGE & LIF $587 \mathrm{~nm}, 607 \mathrm{~nm}$ & $\lg G$ & $\begin{array}{l}\text { High-throughput glycosylation } \\
\text { analysis }\end{array}$ & & & {$[53]$} \\
\hline CGE & LIF & $\lg G$ & Size heterogeneity of reduced $\mathrm{mAb}$ & BC SDS-Mw gel buffer & BFS & {$[51]$} \\
\hline CGE & LIF $488 \mathrm{~nm}, 560 \mathrm{~nm}$ & $\lg G$ & Stability testing, degradation testing & BC SDS gel buffer & BFS & {$[52]$} \\
\hline CGE & LIF $488 \mathrm{~nm}, 520 \mathrm{~nm}$ & $\lg G$ & $\begin{array}{l}\text { High-throughput glycosylation } \\
\text { analysis }\end{array}$ & $\begin{array}{l}\text { Sciex N-CHO carbohy- } \\
\text { drate separation gel buf- } \\
\text { fer }\end{array}$ & $\mathrm{eCaP}^{\mathrm{TM}} \mathrm{N}-\mathrm{CHO}$ & {$[36]$} \\
\hline CGE & LIF $488 \mathrm{~nm}, 520 \mathrm{~nm}$ & mAb & Glycosylation analysis & $\begin{array}{l}\text { BC carbohydrate separa- } \\
\text { tion gel buffer }\end{array}$ & PVA & {$[33]$} \\
\hline CGE & UV $214 \mathrm{~nm}$ & Rituximab and biosimilar & $\begin{array}{c}\text { Biosimilarity assessment } \\
\text { Size heterogeneity of reduced mAb }\end{array}$ & & & {$[47]$} \\
\hline CGE & UV $214 \mathrm{~nm}, 280 \mathrm{~nm}$ & Fc-Fusion protein & Characterization of aggregation & BC SDS-Mw gel buffer & BFS & [37] \\
\hline CGE & LIF $488 \mathrm{~nm}, 512 \mathrm{~nm}$ & $\mathrm{mAb}$ & Glycosylation profiling & $\begin{array}{l}\text { BC gel buffer } \\
\text { AB POP-7polymer }\end{array}$ & $\begin{array}{l}\text { BFS } \\
\text { PVA }\end{array}$ & [32] \\
\hline CGE & LIF $488 \mathrm{~nm}, 560 \mathrm{~nm}$ & $\begin{array}{l}\text { Trastuzumab, pertu- } \\
\text { zumab }\end{array}$ & $\begin{array}{l}\text { Size heterogeneity of intact and } \\
\text { reduced } \mathrm{mAb}\end{array}$ & $\mathrm{BC}$ sieving gel buffer & BFS & {$[48]$} \\
\hline CGE & LIF $488 \mathrm{~nm}, 520 \mathrm{~nm}$ & $\lg G$ & Core fucosylation analysis & $\begin{array}{l}\mathrm{BC} \mathrm{N}-\mathrm{CHO} \text { carbohydrate } \\
\text { separation gel buffer }\end{array}$ & $\mathrm{eCaP}^{\mathrm{TM}} \mathrm{N}-\mathrm{CHO}$ & {$[112]$} \\
\hline CGE & LIF & 3 humanized mAbs & Size heterogeneity of reduced $\mathrm{mAb}$ & BC SDS-Mw gel buffer & & {$[50]$} \\
\hline CGE & UV $220 \mathrm{~nm}$ & $\mathrm{mAb}$ & Protein quantification & BC SDS-Mw gel buffer & BFS & {$[113]$} \\
\hline CGE & UV $220 \mathrm{~nm}$ & mAb and conjutated & Conformational behavior & $\begin{array}{l}30 \mathrm{mM} \text { Tris } \mathrm{pH} 8.5 \mathrm{SDS} \\
(5-30 \mathrm{mM})\end{array}$ & $\mathrm{HPC}$ & [31] \\
\hline CGE & UV 280 nm & vcMMAE-ADC & Profiling ADC positional isomers & BC SDS-Mw gel buffer & BFS & {$[54]$} \\
\hline CGE & LIF $325 \mathrm{~nm}, 405 \mathrm{~nm}$ & $\begin{array}{l}\text { Cetuximab, infliximab, } \\
\text { tocilizumab, bvacizumab, } \\
\text { gemtuzumab ozogami- } \\
\text { cin, adalimumab }\end{array}$ & Glycosylation analysis & $\begin{array}{l}100 \text { mM Tris-borate } \mathrm{pH} \\
8.3,5 \% \text { PEG } 70000\end{array}$ & DB-1 & [38] \\
\hline CGE & LIF $488 \mathrm{~nm}$ & $\lg G$ & Quantitative impurity analysis & BC SDS-Mw gel buffer & BFS & {$[45]$} \\
\hline
\end{tabular}




$\begin{array}{ll}\text { CGE } & \text { UV } 220 \mathrm{~nm} \\ \text { CGE } & \text { UV } \\ \text { CGE } & \text { LIF } 488 \mathrm{~nm}, 520 \mathrm{~nm} \\ \text { CGE } & \text { LIF } 488 \mathrm{~nm}, 520 \mathrm{~nm} \\ \text { CGE } & \text { LIF } \\ \text { CGE } & \text { LIF } 488 \mathrm{~nm}, 520 \mathrm{~nm} \\ \text { CGE } & \text { UV } 220 \mathrm{~nm} \\ \text { CGE } & \text { LIF } 488 \mathrm{~nm} \\ \text { CGE } & \text { LIF } 488 \mathrm{~nm} \\ \text { CGE } & \text { UV } 220 \mathrm{~nm} \\ \text { CGE } & \text { LIF } 488 \mathrm{~nm}, 520 \mathrm{~nm} \\ \text { CGE } & \text { LIF } 488 \mathrm{~nm}, 520 \mathrm{~nm} \\ \text { CGE } & \text { LIF } 488 \mathrm{~nm}, 520 \mathrm{~nm} \\ \text { CGE } & \text { UV } 220 \mathrm{~nm} \\ \text { CGE } & \text { UV } 220 \mathrm{~nm} \\ \text { CGE } & \text { UV } 220 \mathrm{~nm} \\ \text { CGE } & \text { UV } 220 \mathrm{~nm} \\ \text { CGE } & \text { LIF } 543.5 \mathrm{~nm} \\ & \end{array}$

CGE

UV $220 \mathrm{~nm}$

iCIEF

UV $280 \mathrm{~nm}$

CIEF
Anti-CD4 mouse IgG 2a

$$
\begin{gathered}
\operatorname{lgG1} \\
\text { Ch14.18 }
\end{gathered}
$$

Mouse IgG

Mouse serum IgG

Bovin serum IgG

Palivizumab, Rituximab

Fc-Fusion protein

$\lg G 1$

$\operatorname{lgG1}$

IgG1

$\lg G$

$\lg G 1$

Rituximab

Goat IgG, Rat IgG

$\mathrm{mAb}$

$\lg G 2$

$\operatorname{lgG} 2$

$\mathrm{mAb} 8 \mathrm{E} 11$

mAb1

Avastin and biosimilar

$\operatorname{lgG1}$
Characterization of Ricin A-chain immunotoxins

mAb purity analysis

Glycosylation analysis

Potentially immunogenic

carbohydrate residues in biologics

Size heterogeneity of reduced $\mathrm{mAb}$

Glycosylation analysis

Disulfide scambled forms during purification process

Size heterogeneity of reduced mAb

Glycation characterization

Size heterogeneity of reduced mAb

under copper and high pH stress

Glycosylation analysis

Glycosylation analysis

Characterization of oligosaccharides

Size heterogeneity of reduced $\mathrm{mAb}$

Size heterogeneity of reduced $m A b$ Size heterogeneity of reduced $\mathrm{mAb}$

Disulfide isomer heterogeneity

Quantitative study of stereospecific binging of mAb to BPDE-dG adducts

Size heterogeneity of reduced mAb

Charge heterogeneity of intact mAb

Glycosylation analysis
Bio Rad CE-SDS buffer

BC SDS-MW gel buffer

BC Carbohydrate label-

ing and analysis kit

BC Carbohydrate separa-

tion gel buffer

60 mM Tris-borate 0.1\%

SDS pH 8.45

$100 \mathrm{mM}$ Tris- $\mathrm{CH}_{3} \mathrm{CO}_{2} \mathrm{H}$

$0.05 \%$ HPC pH 7.0

BC SDS-Mw gel buffer

BC coated capil-

$\mathrm{eCaP}^{\mathrm{TM}} \mathrm{N}-\mathrm{CHO}$

$B C$ sieving gel buffer

$\mathrm{BC}$ sieving gel buffer

$7.5 \mathrm{mM} \mathrm{CH}_{3} \mathrm{CO}_{2} \mathrm{NH}_{3}$

$25 \mathrm{mM} \mathrm{H}_{3} \mathrm{BO}_{3}$ 1.5\% LPA

BC Carbohydrate separa-

tion gel buffer

$100 \mathrm{mM}$ Tris- $\mathrm{CH}_{3} \mathrm{CO}_{2} \mathrm{H}$

$0.05 \%$ HPC pH 7.0

BC SDS-MW gel buffer

$B C$ sieving gel buffer

BC SDS-MW gel buffer

BC SDS-MW gel buffer

$14 \mathrm{mM}$ Tris $108 \mathrm{mM}$ gly-

cine $10.5 \mathrm{mM} \mathrm{CH}_{3} \mathrm{CO}_{2} \mathrm{H}$

$\mathrm{pH} 7.5$

30 mM Tris 160 mM gly-

cine $\mathrm{pH} 8.5$

25 mM citrate-phos-

phate

1\% SDS pH 6.5

Amph: 3-10:8-10.5 (1:1)

$+0.35 \% \mathrm{MC}$
BFS

BFS

lary

BFS

DB-1

BFS

[117]

[118]

[119]

[120]

[121]

[122]

BFS
BFS 
ICIEF UV $280 \mathrm{~nm}$ $\operatorname{lgG1}$ ICIEF UV $280 \mathrm{~nm}$

ICIEF UV $280 \mathrm{~nm}$ iCIEF UV $280 \mathrm{~nm}$

CIEF UV $280 \mathrm{~nm}$

iCIEF

UV $280 \mathrm{~nm}$

CIEF

UV $280 \mathrm{~nm}$

CIEF

UV $280 \mathrm{~nm}$

iCIEF

UV $280 \mathrm{~nm}$

iCIEF

CIEF BC Protoco

CIEF UV $280 \mathrm{~nm}$

iCIEF PBD-ADC, vcMMAE-ADC

Charge heterogeneity of intact $\mathrm{mAb}$ Heat-stress stability

Characterization of C-terminal Lys

Charge heterogeneity of reduced

$$
m A b
$$

Trastuzumab, biosimilar

Charge profiling, stability testing of biosimilar

Human IgG

MAK-33 IgG

Cetuximab

Trasbuzumab

Bevacizumab

Trastuzumab, pertuzumab

3 humanized mAbs

\section{Conbercept}

usion protein

Charge heterogeneity of intact mAb

Robust protein reagent characteriza-

Quality assurance based on charge variants.

Charge heterogeneity of reduced

$$
\mathrm{mAb}
$$

Structural characterization Charge heterogeneity of intact mAb

Charge heterogeneity of intact mAb
Charge heterogeneity of intact $\mathrm{mAb}$

Cath: $0.08 \mathrm{M} \mathrm{NaOH}$

Amph: Pharmalyte

Amph: 3-10:8-10.5

Anol: $200 \mathrm{mM} \mathrm{H}_{3} \mathrm{PO}_{4}$ Cath: $300 \mathrm{mM} \mathrm{NaOH}$

Amph: 3-10,

$0.35 \% \mathrm{HPMC}$

Amph: 3-10

Anol: $200 \mathrm{mM} \mathrm{H}_{3} \mathrm{PO}_{4}$

Cath: $300 \mathrm{mM} \mathrm{NaOH}$

Amph: 3-10

Anol: $200 \mathrm{mM} \mathrm{H}_{3} \mathrm{PO}_{4}$ Cath: $300 \mathrm{mM} \mathrm{NaOH}$ $+0.04 \%$ HPMC both

Amph: 3-10

Anol: $80 \mathrm{mM} \mathrm{H}_{3} \mathrm{PO}_{4}$ Cath: $100 \mathrm{mM} \mathrm{NaOH}$ $+0.1 \%$ HPMC both

BC Protocol

Amph: 5-8:8-10.5 (3:7)

Anol: $0.08 \mathrm{M} \mathrm{H}_{3} \mathrm{PO}_{4}$

Cath: $0.1 \mathrm{M} \mathrm{NaOH}$

$+0.1 \%$ HPMC both 
Charge heterogeneity of intact mAb

$\mathrm{H}_{3} \mathrm{PO}_{4}$

Cath: $0.1 \mathrm{M} \mathrm{NaOH}$

$+0.1 \%$ HPMC both

Amph: 5-8:8-10.5

Anol: $0.08 \mathrm{M} \mathrm{H}_{3} \mathrm{PO}_{4}$

Cath: $0.1 \mathrm{M} \mathrm{NaOH}$

Charge heterogeneity of intact mAb

Amph: 3-10, 8-10.5

Anol: $0.2 \mathrm{M} \mathrm{H}_{3} \mathrm{PO}_{4}$

CIEF UV $280 \mathrm{~nm}$

$\operatorname{lgG1}$

iCIEF

UV $280 \mathrm{~nm}$

mAb

ICIEF UV $280 \mathrm{~nm}$

iCIEF UV $280 \mathrm{~nm}$

iCIEF

Human mAb

Fab fragment of human $\mathrm{mAb}$

$\lg \mathrm{I} 1 \lg G 4$

Gemtuzumab ozogamicin

$\operatorname{lgG} 2$

Avastin and biosimilar

Anti-HAS-mAb

Fc1 or anti-CD40 IgG1

$\lg \mathrm{g} 1$
Charge heterogeneity of intact mAb Interlaboratory study

Cath: $0.3 \mathrm{M} \mathrm{NaOH}$

Amph: 5-8

Anol: $0.2 \mathrm{M} \mathrm{H}_{3} \mathrm{PO}_{4}$

Cath: $0.3 \mathrm{M} \mathrm{NaOH}$

High throughput profiling of charge heterogeneity

Amino acid substitution identification

Identification of isomerization and racemization of aspartate in the AspAsp motifs

Net Charge assessment

Charge heterogeneity of intact mAb with a cytotoxic antitumor antibiotic

Charge heterogeneity of intact mAb

Charge heterogeneity of intact $\mathrm{mAb}$

Determination of binding constant

Characterization of Fc1 aggregation

Charge heterogeneity of intact $\mathrm{mAb}$ Interlaboratory study
Amph: 3-10

Anol: $0.08 \mathrm{M} \mathrm{H}_{3} \mathrm{PO}_{4}$

Cath: $0.1 \mathrm{M} \mathrm{NaOH}$

Amph: 5-8, 8-10.5

Amph: 3-10:6.7-7.7 (1:1)

Anol: $0.08 \mathrm{M} \mathrm{H}_{3} \mathrm{PO}_{4}$

Cath: $0.1 \mathrm{M} \mathrm{NaOH}$

+0.1\% HPMC both

Amph: 3-10:8-10.5

15/85

Amph: 3-10

Anol: $0.2 \mathrm{M} \mathrm{H}_{3} \mathrm{PO}_{4}$

Cath: $0.3 \mathrm{M} \mathrm{NaOH}$

Amph: 3-10

$500 \mathrm{mM}$ EACA/0.1M HCl

2 mM TETA pH 5.7

$0.05 \%$ HPMC

$50 \mathrm{mM}$ borate $\mathrm{pH} 9.3$

$400 \mathrm{mM} \mathrm{EACA} / \mathrm{CH}_{3} \mathrm{CO}_{2} \mathrm{H}$

2 mM TETA pH 5.7

$0.05 \%$ HPMC 

cizumab, rituximab, tras-

$$
\text { tuzumab }
$$

$\begin{array}{ll}\text { CZE } & \text { UV } 214 \mathrm{~nm} \\ \text { CZE } & \text { UV } 200 \mathrm{~nm}\end{array}$

CZE

UV $214 \mathrm{~nm}$

CZE

UV $214 \mathrm{~nm}$

CZE

CZE

UV 214 and $254 \mathrm{~nm}$

UV $214 \mathrm{~nm}$

CZE

UV $214 \mathrm{~nm}$

CZE

UV $214 \mathrm{~nm}$

MZE

ME-SDS LIF $635 \mathrm{~nm}, 700 \mathrm{~nm}$

MZE

UV $214 \mathrm{~nm}$

MZE

Chemiluminescence

MIEF
Trastuzumab, pertuzumab

Inflixumab, rituximab, bevacizumab, cetuximab, tocilizumab

Rituximab, trastuzumab and biosimilar, ranibizumab, bevacizumab,In-

fliximab and biosimilar

$\lg G 1$

Bevacizumab, ranibizumab

$\lg G$

$\mathrm{mAb}$

$\lg G$

IgG1, IgG4

$\lg G$

Human IgG

Anti-cortisol mouse Ab

Cetuximab

Trasbuzumab
Charge heterogeneity of intact and reduced $\mathrm{mAb}$

Charge heterogeneity of intact $\mathrm{mAb}$

Charge heterogeneity of intact mAb

$200 \mathrm{mM}$ EACA $/ \mathrm{CH}_{3} \mathrm{CO}_{2} \mathrm{H}$

$30 \mathrm{mM} \mathrm{CH}_{3} \mathrm{CO}_{2} \mathrm{Li} \mathrm{pH} 4.8$

$150 \mathrm{mM}$ EACA $/ \mathrm{CH}_{3} \mathrm{CO}_{2} \mathrm{H}$

$20 \mathrm{mM} \mathrm{CH}_{3} \mathrm{CO}_{2} \mathrm{Li} \mathrm{pH} 5.5$

0.05 HPMC

Determination of Charge variants

$20 \mathrm{mM} \mathrm{CH}_{3} \mathrm{CO}_{2} \mathrm{Na}$

2 mM TETA pH 6.0

03\% PEO

Effective electrophoretic mobilities and charges

0.016-0.16 mM PBS pH

7.4

Rapid analysis of Charge heterogeneity of intact $\mathrm{mAb}$

High throughput profiling of charge heterogeneity

Charge heterogeneity of intact mAb and disulfide isomers

Size heterogeneity of reduced mAb

Charge heterogeneity of $\mathrm{mAb}$

Stability testing, degradation testing

Charge heterogeneity of intact mAb

Homogeneous immunoassay of corti-

$$
\text { sol }
$$

Quality assurance based on charge variants.
$400 \mathrm{mM}$ EACA $/ \mathrm{CH}_{3} \mathrm{CO}_{2} \mathrm{H}$

2 mM TETA pH 5.7

$0.05 \%$ HPMC

$20 \mathrm{mM}$ EACA $/ \mathrm{CH}_{3} \mathrm{CO}_{2} \mathrm{H}$

$0.01 \%$ polysorbate $20 \mathrm{pH}$

4.4, 0.05\% HPMC

$600 \mathrm{mM}$ EACA $/ \mathrm{CH}_{3} \mathrm{CO}_{2} \mathrm{H} \quad \mathrm{HPMC}$

$0.1 \%$ HPMC pH 5.5

HT protein express gel

matrix + fluorescent dye

$400 \mathrm{mM}$ EACA $/ \mathrm{CH}_{3} \mathrm{CO}_{2} \mathrm{H}$

2 mM TETA pH 5.7

0.05\% HPMC

$10 \mathrm{mM}$ phosphate

$+0.08 \%$ Tween 20

$+1 \%$ luminol

Amph: 3-10

Anol: $40 \mathrm{mM} \mathrm{C}_{4} \mathrm{H}_{7} \mathrm{NO}_{4}$

HPMC

neutral

BFS

HPMC

HPMC
PB

HPMC

PB-DS-PB

Ultratrol ${ }^{\mathrm{TM}} \mathrm{LN}$

Ultratrol ${ }^{\mathrm{TM}} \mathrm{HR}$

HPC

HPMC

PEO

BFS 
Bevacizumab

\section{MZE}

MZE

UV $280 \mathrm{~nm}$

MZE Chemiluminescence

MZE

CZE-MS ESI-QTOF-MS

MZE-MS ESI-QTOF-MS

CZE-MS ESI-QTOF-MS/MS

CZE-MS ESI-QTOF-MS

CZE-MS ESI-Orbitrap-MS

CZE-MS ESI-Orbitrap-MS

MZE-MS ESI-TOF-MS

CZE-MS MALDI-TOF-MS

$\begin{array}{ll}\text { CZE-MS } & \text { ESI-QTOF-MS/MS } \\ \text { CZE-MS } & \text { ESI-Orbitrap-MS/MS } \\ \text { CZE-MS } & \text { ESI-QTOF-MS/MS }\end{array}$

CZE-MS MALDI-TOF-MS
IgG1, IgG2

$\mathrm{mAb}$

Mouse anti-T4 mAb IGN311

Brentuximab vedotin vcMMAE-ADC

$A D C$

Trastuzumab

Cetuximab

Anti-human IgG4

Human mAb

Inflixumab, IgG2

Cetuximab

Trastuzumab, cetuximab 2 other mAbs

Trastuzumab

Trastuzumab, cetuximab Biosimilar candidates

Trastuzumab
Cath: $100 \mathrm{mM} \mathrm{NaOH}$

$+0.1 \%$ HPMC both

Glycosylation analysis High throughput profiling of charge heterogeneity

Immunoassay

Impurity testing

Intact, middle-up and bottom-up characterizaiton

Characterization of intact ADC

Asparagine deamidation and iso Apartic acid isomerization characteri-

$$
\text { zation }
$$

Fc/2 dimers characterization

Inlet vial: $200 \mathrm{mM}$ EACA

$+25 \mathrm{mM} \mathrm{CH}_{3} \mathrm{CO}_{2} \mathrm{Na} \mathrm{pH}$

5.7

Outlet vial: $25 \mathrm{mM}$

$\mathrm{CH}_{3} \mathrm{CO}_{2} \mathrm{Na} \mathrm{pH} 5.7$

Charge heterogeneity of reduced

$$
\text { mAb }
$$

Host cell Impurities detection

$0.1 \% \mathrm{COOH}$

SL: $10 \% \mathrm{CH}_{4} \mathrm{O} / 0.5 \% \mathrm{COOH}$

$0.1 \% \mathrm{COOH}$

SL: $10 \% \mathrm{CH}_{4} \mathrm{O} / 0.5 \% \mathrm{COOH}$

Charge heterogeneity of intact $\mathrm{mAb}$

100 mM PBS

$+10 \mathrm{~g} / \mathrm{L}$ NHS-PEG

Inlet vial: $200 \mathrm{mM}$ EACA

$+25 \mathrm{mM} \mathrm{CH}_{3} \mathrm{CO}_{2} \mathrm{Na} \mathrm{pH}$

5.7

Outlet vial: $25 \mathrm{mM}$

$\mathrm{CH}_{3} \mathrm{CO}_{2} \mathrm{Na}$ pH 5.7

Sequence coverage, glycosylation and

$10 \% \mathrm{CH}_{3} \mathrm{CO}_{2} \mathrm{H}$

$10 \% \mathrm{CH}_{3} \mathrm{CO}_{2} \mathrm{H}$

Glycosylation profiling

$10 \% \mathrm{CH}_{3} \mathrm{CO}_{2} \mathrm{H}$

Charge heterogeneity of intact mAb

400 mM EACA
BFS

HPMC

Brij 35

BFS

EG, APS

BFS

HPC

APS

HPC

BFS

BFS

HPC 
MALDI-TOF-MS/MS

$\begin{array}{cc}\begin{array}{c}\text { Micro- } \\ \text { chip-LC- } \\ \text { CE-MS }\end{array} & \text { ESI-TOF-MS } \\ \text { CZE-MS } & \text { ESI-QTOF-MS } \\ \text { CZE-MS } & \text { ESI-TOF-MS } \\ \text { CZE-MS } & \text { ESI-QTOF-MS }\end{array}$

CIEF-MS ESI-Orbitrap-MS

CZE-MS ESI-TOF-MS

CZE-MS ESI-TOF-MS
Sequence coverage, glycosylation and

$10 \% \mathrm{CH}_{3} \mathrm{CO}_{2} \mathrm{H}$

BFS

PTMs characterization

Glycosylation profiling

40 mM EACA, 131

PVA

$\mathrm{mM}$ acetic acid $\mathrm{pH} 4$

$100 \mathrm{mM}$ EACA, $700 \mathrm{mM}$

ammonia in $30: 70 \mathrm{H}_{2} \mathrm{O}$ /

$\mathrm{CH}_{4} \mathrm{O}$ pH 10

Amph: 3-10

LPA

Anol: $0.1 \% \mathrm{COOH} \mathrm{pH} 2.5$

Cath: $0.3 \% \mathrm{NH}_{3} \mathrm{OH}$ pH 11

$10 \% \mathrm{CH}_{3} \mathrm{CO}_{2} \mathrm{H}$

PVA

CE-MS interfaces comparison

Charge heterogeneity of reduced

mAb

$10 \%-30 \% \mathrm{CH}_{3} \mathrm{CO}_{2} \mathrm{H}$

LPA

Middle up analysis

Table 1. Application and CE methods for the analysis of IgG, biosimilars, Fc-fusion proteins and ADCs in the years $2010-2015$

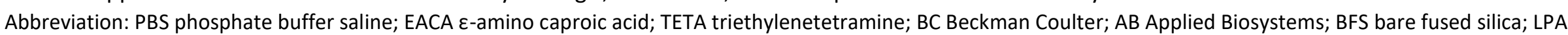

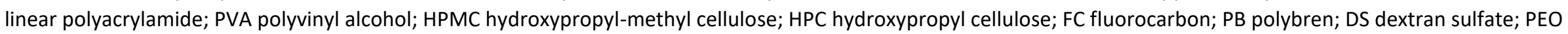
Polyethylene oxide; APS aminopropylsilane; APTES aminopropyltriethoxysilane 